PNL-2596

UC-91

\title{
Evaluation of Land Disposal and Underground Injection of Shale Oil Wastewaters
}

B. W. Mercer

A. C. Campbell

W. Wakamiya

May 1979

Prepared for the U.S. Department of Energy under Contract EY-76-C-06-1830

Pacific Northwest Laboratory

Operated for the U.S. Department of Energy by Battelle Memorial Institute 


\title{
NOTICE
}

This report was prepared as an account of work sponsored by the United States Government. Neither the United States nor the Department of Energy, nor any of their employees; nor any of their contractors, subcontractors, or their employees. makes any warranty. express or implied, or assumes any legal liability of responsibility for the accuracy, completeness of usefulness of any information. apparatus, product or process disclosed, or represents that its use would not infringe privately owned rights.

The views, opinions and conctusions contained in this repon are those of the contractor and do not necessarily represent those of the United States Covernment or the United States Department of Energy.

\author{
PACIFIC NORTHWEST LABORATORY \\ operated by \\ BATTELLE \\ for the \\ UNITED STATES DEPARTMENT OF ENERGY \\ Under Contract EY-76-C-06-1830
}

\begin{abstract}
Printed in the United States of America
Availabie from

National Testinical Information Service

United States Department of Commerce

5235 Port Royal Road

Springfield, Virginia 22151
\end{abstract}

Price: Printed Copys

2. Microfiche $\$ 3.00$

NTis

-Pages Selling Price

$\begin{array}{ll}001-025 & 54.00 \\ 026-050 & 51.50 \\ 057-075 & 55.25 \\ 076-100 & 56.00 \\ 101-125 & 56.50 \\ 126-150 & 57.25 \\ 151-175 & 59.00 \\ 176-200 & 59.00 \\ 201-225 & 59.25 \\ 226-250 & 59.50 \\ 251-255 & 510.75 \\ 256-300 & 511.00\end{array}$




\section{8}

EVALUATION OF LAND DISPOSAL AND UNDERGROUND INUECTION OF SHALE OIL WASTEWATERS

B. W. Mercer

A. C. Campbe ]1

W. Wakamiya

May 1979

Prepared for

the U.S. Department of Energy

under Contract EY-76-C-06-1830

Pácific Northwest Laboratory

Richland, Washington 99352 
. 


\section{SUMMARY}

A study was undertaken using literature information sources to evaluate land disposal and underground injection for the disposal of shale oil wastewaters. Land disposal utilizes the interactions between plants and the soil surface and matrix to renovate wastewater for discharge to groundwater or surface waters. Underground injection is an alternative disposal method for wastewaters that are either too expensive to treat or cannot be adequately treated by conventional processes.

The results of this study indicate that the salinity of retort water, the principal wastewater generated by shale oil recovery operations, will be too high in most cases for irrigation of cover crops needed for effective stabilization by land disposal. Furthermore, large storage lagoons would be required to hold the retort water during the long winters encountered in the oil shale regions of Colorado, Wyoming and Utah. Land disposal cannot be carried out during prolonged periods of freezing weather. Additional problems which may arise with land disposal include air pollution from volatile constituents and groundwater pollution from refractory organics and dissolved salts in the retort water. Pretreatment requirements include the removal of ammonia which is present at toxic concentrations in retort water.

Underground injection of retort water may be permitted in regions possessing favorable geological characteristics. It is anticipated that this method would be used as a last resort where effective or reasonably priced treatment technology is not available. Regulatory restraints are expected to 1 imit the use of underground injection for disposal of highly polluted shale oil wastewaters. Proving the confinement of injected wastes, a frequently difficult and expensive task, will be required to assure protection of drinking water resources. 


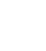

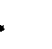

. 


\section{CONTENTS}

SUMMARY

INTRODUCTION.

CONCLUSIONS

LAND DISPOSAL

POTENTIAL FOR LAND DISPOSAL IN SHALE OIL DEVELOPMENT REGIONS . . 5

Area Limitations for Land Treatment of Retort Water . . . 5

SUITABILITY OF RETORT HATER FOR LAND TREATMENIT ANID DISPOSAL • • 8

UNDERGROUND INUECTION.

UNDERGROUND INJECTION WELL . . . . . . . . . . . . . . 16

Disposal Zone Completion . . . . . . . . . . . . 18

WASTE CHARACTERISTICS . . . . . . . . . . . . . . 18

DISPOSAL SITE SELECTION . . . . . . . . . . . . . . . . 19

WELL OPERATION AND MONITORING . . . . . . . . . . . 23

ECONOMICS . . . . . . . . . . . . . . . . . . . 23

LEGAL CONSIDERATIONS . . . . . . . . . . . . . . . 26

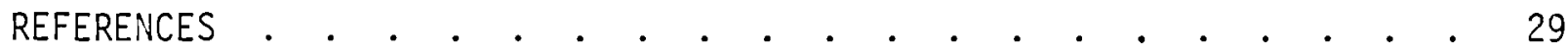

ACKNOWLEDGMENTS. . . . . . . . . . . . . . . . . . . . . . . . . . .

REVIEW OF TECHNOLOGY FOR LAND DISPOSAL OF WASTEWATER . . . . . . . A-

TREATMENT PROCESSES. . . . . . . . . . . . . . . . A-1

Mechanisms . . . . . . . . . . . . . . A-1

Land Application Methods . . . . . . . . . . . A-3

DESIGN CONSIDERATIONS . . . . . . . . . . . . . . . A-8

Wastewater Quality . . . . . . . . . . . A-8 
Environmental Characteristics. . . . . . . . . A-9

OPERATION AND MAINTENANCE CONSIDERATIONS. . . . . . . . . A-14

Environmental Assessment . . . . . . . . . A-15

APPENDIX REFERENCES . . . . . . . . . . . . . . A-16 


\section{FIGURES}

1 Sodium and Salinity Hazard . . . . . . . . . . . 15

2 Disposal Well . . . . . . . . . . . . . . . . 17

3 Deep Well Disposal Sites . . . . . . . . . . . . 21

4 A Pressure-Flow Test of a Deep-Well . . . . . . . . 25

A-1 Basic Methods of Application . . . . . . . . . . . . A-5

\section{TABLES}

1 Area Descriptions for 0 il Shale Lands in Colorado, Utah and Wyoming. . . . . . . . . . . . . . 6

2 Retort Water Quality Data Pertinent to Land Disposal . . . 10

3 Recommended Limits of Specific Ions in Irrigation Water Compared with Those Found in Retort Waters from Simulated In Situ Retorts at the Laramie Energy Technology Center 13

4 Problems Relative to Monitoring a Waste Injection Project . 24

A-1 Assumed Model Disposal Conditions and Characteristics for Land Applications of Wastewaters . . . . . . . A-4

A-2 EPA Regulations on Interim Primary Drinking Water Standards . . . . . . . . . . . . . . A $A-12$

A-3 Reconmended and Estimated Maximum Concentrations of

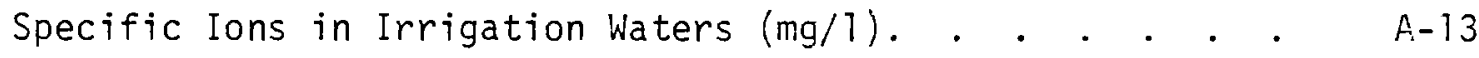




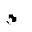

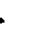

. 


\section{EVALUATION OF LAND DISPOSAL AND UNDERGROUND INJECTION \\ OF SHALE OIL WASTEWATERS}

\section{INTRODUCTION}

Commercial development of the enormous energy resources of domestic oil shale is considered by many to be a vital part of the National Plan for energy self-sufficiency. Most of the readily available, high-grade oil shale deposits are located in the States of Wyoming, Colorado and Utah. Commercial interest in developing this resource has surfaced several times in this century, but each time economic, political, techrical or legal roadblocks have postponed actual development. However, a considerable amount of private and government-sponsored activity is currently taking place which is expected to culminate in commercial production of shale oil in the 1980s. Included in this activity are numerous studies to evaiuate the environmental impacts associated with large-scale oil shale mining and processing operations. The disposal of wastewaters produced by these operations is an important element to be considered in the overall environmental impact of the developing shale oil industry.

Wastewater can be generated by a number of different sources within a shale oil recovery facility, depending on the location and type of recovery system used. The pollution potential of the wastewater may be high as in the case of retort water or low as in the case of some groundwaters removed from mining areas. The total volume of wastewater to be discharged by shale oil production operations will vary with the method of extraction used and the requirements for upgrading to produce oil which can be pumped through a pipeline. Above-ground retorting facilities may reuse all wastewater streams generated within the mining and processing facilities to moisten spent shale for compacting in the dumping areas. Moisturizing subsurface spent shale is not required for in situ operations; therefore, substantial wastewater discharges are anticipated at these installations. However, about $20 \%$ of the oil shale processed by modified in situ operations will either be aumped or 
more likely processed in above-ground retorts, and wastewater may be used for compacting spent shale from the above-ground retorts.

In situ retorting produces retort water in approximately the same volume as that of the $0 i 1$ produced. Production of 100,000 barrels of oil per day would involve the management of about $16,000 \mathrm{~m}^{3} /$ day of retort water at an in situ facility.

This report addresses the potential application of land disposal and underground injection as disposal options for wastewater generated in the recovery of shale oil. Land disposal is the application of wastewater at the soil/air interface to utilize natural chemical and physical reactions for purifying the wastewater as it flows over or into the soil. The Federal Water Pollution Control Act, PL 92-500 (?) has focused attention on land application as an alternative for effective treatment and disposal of wastewater and sludges to comply with zero discharge requirements stated for 1985. Irrigation is one such application.

Uncierground injection is a disposal method which involves little or no purification in the geological strata receiving the wastewater. Underground injection is generally used as a last resort for wastewater that cannot be economically treated and disposed of above ground. 


\section{CONCLUSIONS}

The results of this investigation indicate that both the wastewater characteristics and the climate of the $0 i 1$ shale regions of Wyoming, Colorado and Utah do not appear favorable for land treatment and disposal of retort water generated by shale oil recovery operations in these areas. For example, retort waters produced by simulated retorts or field tests show high salinity which in most cases is sufficient to render this wastewater unsuitable for irrigation of typical cover crops. It is possible that salt-resistant cover crops may be substituted; however, the potential for groundwater pollution from excessive salt remains. The concentration of dissolved solids in the waste water applied to soil is further increased by evaporation at the surface and dissolution of salts from the soil.

The long winters characteristic of the oil shale regions in Wyoming, Colorado and Utah adversely affect the cost of land disposal of wastewater by irrigation and overland runoff because of the large wastewater storage requirement. Irrigation and overland runoff cannot be conducted during freezing weather and application rates must be reduced during cool weather. Rapid infiltration is possible during freezing weather, but it is doubtful this method would be feasible for retort water with high concentrations of organic matter.

The presence of high concentrations of refractory or nonbiodegradable organics is also a potential problem with iand disposal of retort water. These organics are not expected to degrade rapidiy in the soil and present a further threat to groundwater quality if leached from the overlying soil. If very low loading rates are required to allow sufficient time for decomposition of refractory organics, considerable costs may be iricurred.

The possible presence of toxic inorganic materials in the water must also be considered. Initial results indicate that the concentration of aluminum (Al), copper (Cu), zinc ( $Z n$ ) and molybdenum (Mo) may be sufficient in some cases to cause problems with the cover crop or the biota in the soil. 
The question of toxic organics in the wastewater remains to be resolved. Air pollution from volatile constituents in the waste or from aerosols is also a distinct possibility. The odor of retort water as well as toxic substances may be a problem to populations living downwind of the land disposal area.

Underground injection is a viable disposal method for shale oil wastewaters where geological conditions are favcrable; however, regulatory restraints are expected to limit its use for disposal of highly polluted shale oil waters. Proof of confinement of injected wastes will be required to assure protection of drinking water resources, and this is often difficult and expensive to accomplish.

Great care must be exercised in the selection of an underground disposal site for liquid wastes. The suitability of a specific location of a waste injection well must be evaluated by a detailed geological subsurface investigation. One of the primary purposes of this investigation is to assure confinement of the wastes once these are injected into the desired underground zone. Injection of highly toxic or polluted wastes are expected to require greater assurances of confinement to avoid any possibility of contaminating drinking water supplies.

The typically high BOD concentration found in retort water may cause plugging problems in the injection zone as a result of biological growth. The retort water generaliy contains salts of aliphatic acids which are readily biodegradable by anaerobic processes. A very long residence time may be required in the injection zone to permit further reaction. 


\section{LAND DISPOSAL}

One of the goals of waste treatment management plans and practices, as stipulated by PL $92-500,(1)$ is to provide for the application of the best practicable waste treatment technology before any discharges are made into receiving waters. Reclaiming and recycing of water and confining pollutants are to be carried out to ensure protection of water and other environmental components. In other words, removal of follutants from a wastewater must not be accomplished at the expense of air, land, and water resource quality. Alternatives, such as another possible location, another method of disposal or recycling of pollutants, are to be considered among the alternatives of wastewater treatment and disposal. The choice is made by each municipality or industry, based on cost effectiveness and treatment objectives and requirements.

\section{POTENTIAL FOR LAND DISPOSAL IN SHALE OIL DEVELOPMENT REGIONS}

Parts of Colorado, Utah and Wyoming contain oil shale deposits of the Green River Formation. These areas have been closely studied to determine their potential for commercial development. The U.S. Department of Interior studied the impacts of developing the areas and general area descriptions were gathered. (2) Serious consideration of land disposal as a treatment alternative requires specific site study and the material presented in this section is designed to represent the overall picture of the potential appiication and associated probiems of land treatment.

Area Limitations for Land Treatment of Retort Water

Climatic, soil and use data for Colorado's Piceance Creek Basin, Utah's Uinta Basin and the Green River and Washakie Basins of Wyoming are summarized in Table 1. Area classifications are general and will vary to different degrees according to the item under consideration. In many cases, available data are limited and assumptions have been made to facilitate this study. 
TABLE 1. Area Descriptions for 0 il Shale Lands in Colorado, Utah and Wjoming (2)

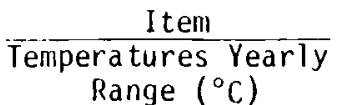

Frost-free season

Precipitation

Winter

Surmer

Wind

Elevation

Groundwater

DS

Use

क)

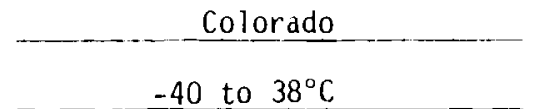

$50-124$ days

30 to $61 \mathrm{~cm}$

Snow, $\angle 50 \%$ of total

Thunderstorms

Gentle

1,750 to $2,700 \mathrm{~m}$

Fresh, saline

250-63,000 $\mathrm{mg} / 1$

Livestock and wildlife, irrigation

Grass and forbs

10 to $60 \%$

Slopes

soil Depth

Soils

Thick valley floors, shallow at high eleyations

Haplor thents, Haplargids, Argiustolls, Haplustolls. Hapluquolls.

- Lothic and shallow

- Calcareous, cambic

- Clays

- High organic matter

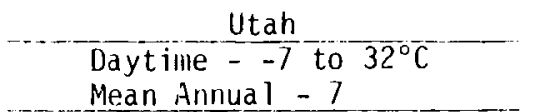

90-218 days

18 to $38 \mathrm{~cm}$

Snow, 45\%

Thunders torms

Irregular and light

1,400 to $>2,400 \mathrm{~m}$

Fresh, saline

237-81, 20C

Livestock and wildlife, sonite drinking water

Hay

Gentle to steep

Shallow

Wyoming

\section{-40 to $32^{\circ} \mathrm{C}$}

\section{0-120 days}

18 to $53 \mathrm{~cm}$

Snow, $75 \%$

Thunderstorms

Relatively strong

2,100 to $2,400 \mathrm{~m}$

Fresh

455-3,600

Stock watering, domestic, oil drilling

Salt tolerant grass

Gentle to steep

$60 \%$ are $<51 \mathrm{~cm}$

$40 \%$ moderately deep

to deep

Torriorthents, Calciorthids, Xerofluverits, Ustifluvents, Torrifluvents.

- Salty dry

- Low organic matter

-Calcic
Haplaraids, Torriorthents, Salorthids.

- Salty

- Low organic matter

- $\mathrm{pH}>7.0$

- High degree base saturation 


\section{Colorado}

Thick valley floors would be ideal locations for irrigation or infiltrationpercolation systems. Steep slopes are common, thereby limiting the number of potential sites. Infiltration-percolation is further limited by the predominant shallow and lithic soils. Soils are typical for semiarid regions and portions include layers with high carbonate, sodium, salts, cation exchange capacity, organic matter and/or clay.

The frost-free season varies according to elevation with the longer seasons at lower elevations. Growing seasons range from 2 to 4 months. Application periods usually extend beyond normal growing seasons and depend on freezing soil and snow. (3) Local conditions determine actual application periods. Large storage lagoons would be required or some other form of treatment during winter months and periods of intensive rainfall. Summer thunderstorms causing flooding would be dealt with on a daily basis.

\section{$\underline{\operatorname{tah}}$}

Soils in the Uinta Basin are generally described as shallow. Deep, alluvial soils are found along some of the larger streams; however, depth to water table may be limiting. Permeability is moderate to low for the majority of soils and surfaces are highly erodible. Soluble salts, carbonate, and organic material concentrations vary by location. Area vegetation ranges from salt tolerant grasses to irrigated crops and pastures.

Daytime temperatures range from -7 to $32^{\circ} \mathrm{C}$ with a mean anrual temperature of $7^{\circ} \mathrm{C}$. The growing season is relatively short, 3 to 7 months, with the average being 4 . Irrigation permits some farming activity in the semiarid basin area. Most rainfall comes from the thunderstorms during the growing season with snow averaging $76 \mathrm{~cm}$ during the winter. Storage requirements capable of handling 5 to 9 months of retort water production would be necessary. Groundwater supplies are fresh in some areas and saline in other and are not extensively used. 
Wyoming

Winters are cold, sometimes dropping to $-40^{\circ} \mathrm{F}$, and summers are short. Annual precipitation is from 18 to $53 \mathrm{~cm}$ and is predominantly winter snow. The frost-free season varies from 50 to 120 days. Large storage area requirements, 8 to 10 months, could be limiting. Relatively strong winds could accentuate odor and aerosol problems from storage lagoons. Livestock and public demands are supplied in some amounts by groundwater.

Shallow, gently sloping soils are representative for the Washakie Basin. Erosion hazards are generally moderate to high. Common soil reactions are alkaline to strongly alkaline. The majority of soils are considered unsuitable for irrigation because salt concentrations are high. Leaching is low as a result of the low rainfall. Salt tolerant grass is the natural ground cover.

SUITABILITY OF RETORT WATER FOR LAND TREATMENT AND DISPOSAL

Wastewater composition is one of the most important factors to be considered when investigating the applicability of land treatment and disposal for a particular wastewater. The general criteria for judging the suitability of a wastewater for land disposal are given below:

1. The organic material must be biologically degradable at reasonable rates.

2. It must not contain materials in concentrations toxic to soil microorganisms. Since some toxic materials may accumulate through adsorption or ion exchange and approach toxic levels after prolonged operation, there must be reasonable assurance that this effect can either be prevented or mitigated.

3. It must not contain substances that wiil adversely affect the quality of the underlying groundwater. In many instances, decisions relative to this aspect of land disposal systems are difficult because of the uncertain nature of available estimating techniques. 
4. It must not contain substances that cause deleterious changes to the soil structure, especialiy its infiltration, percolation and aeration characteristics. An imbalance of sodium ion is a common problem in this regard.

Characteristics relevant to land disposal are presented for a number of different retort waters in Table 2. ${ }^{(4)}$ All of the retort waters, except that from the Utah in situ test site, are from simulated in situ retorts at the Laramie Energy Technology Center and the Lawrence Livermore Laboratory.

High salinity commonly found in the retort water would be toxic to most cover crops. Waters having conductivities greater than 2,250 4 mhos/cm are considered unsuitable for irrigation in most cases. With the possible exception of one sample for which insufficient data are available (University of Southern California No. 1) none of the retort waters in Table 2 would be below 2,250 umhos/cm conductivity following ammonia removal by stripping. Steam stripping tests would be required to establish accurate conductivity values for the ammonia stripped water.

Substances which could affect groundwater quality at a land disposal site receiving retort water are 1 isted below:

- high salinity

- high nitrogen concentrations which yield nitrate on oxidation

- refractory organics which are not oxidized or removed by the soil.

The high salinity found in most retort waters would adversely affect drinking water quality groundwater if sufficient dilution were not available in the aquifer. A limit of $500 \mathrm{mg} / \mathrm{l}$ is recommended for drinking water and this value is exceeded by more than 100\% for all the retort waters 1 isted in Table 2 even after steam stripping for ammonia removal. Furthermore, evaporation of water during irrigation and leaching of salts from the soil will add to the dissolved solids content of the retort water as it percolates to the groundwater. 


\section{TABLE 2. Retort Water Quality Data Pertinent to Land Disposal}

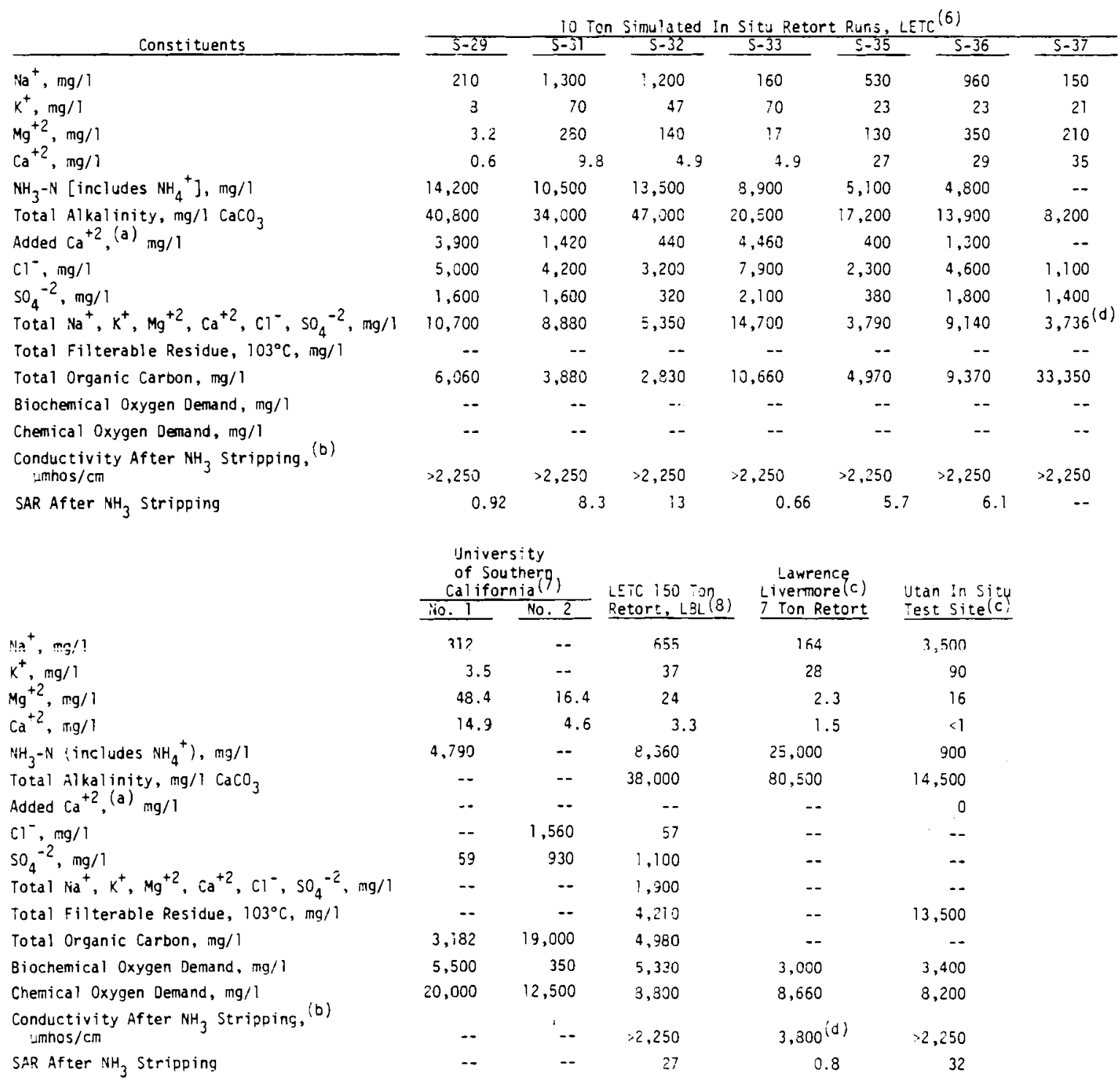

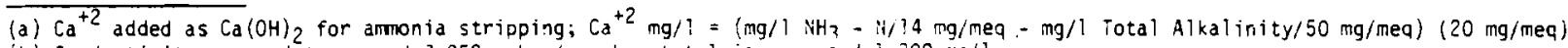
(b) Conductivity assumed to exceed 2,250 :mhos $/ \mathrm{cm}$ when total ions exceed $1,200 \mathrm{mq} / 1$.

(c) Analysis by Pacific Northwest Laboratory.

(d) $\mathrm{NaOH}$ added for stripping ammonia; condlictivity measured on steam stripped water adjusted to $\mathrm{pH} 7$. 
Particular care must be exercised to control the application of nitrogen to the soil. Sufficient nitrogen must be available as a nutrient for growth of the cover crop; however, excessive loading of nitrogen would result in nitrate contamination of the groundwater. Steam stripping can be used to control the concentration of ammonia, but other forms of nitrogen ( $\mathrm{NO}_{3}$ and organic $-N$ ) may dictate the land requirement to attain the desired nitrogen loading. The nitrate and organic $-N$ content of retort water has not been determined on a sufficient number of samples to establish an average or range of values.

Steam stripping of ammonia is more effectively accomplished at high $\mathrm{pH}$ levels. Stripping efficiency is reduced as neutrality is approached and becomes low in acid. Additional alkalinity in the form of lime is frequently added to maintain adequate $\mathrm{pH}$ levels. The addition of lime in the stripping process substitutes $\mathrm{Ca}^{+2}$ ion for ammonium ion which is beneficia? from the standpoint of the ratio of $\mathrm{Na}^{+}$to $\mathrm{Ca}^{+2}$ plus $\mathrm{Mg}^{+2}$. However, if considerable lime is required, the salinity of the steam stripped waste will be high due to the calcium salts present. The alkalinity deficit reported as added $\mathrm{Ca}^{+2}$ (1ime) for steam stripping is given for most of the retort waters in Table 2. Removal of all the ammonia may not be required since some nitrogen will be required for vegetation growth and oxidation of the organic matter in the retort water. In addition to ammonia, nitrogen can be supplied by organicnitrogen and nitrate-nitrogen in the retort water.

The generally high ammonia levels in retort water would be expected to cause toxicity problems if not removed prior to disposal of the water to land. Although removal of the ammonia may be relatively costly, part or a 11 of this cost may be recovered by marketing the ammonia. It is likely that steam stripping would be used to remove the ammonia since this process is well adapted to removal of high concentrations of ammonia from wastewater. Steam stripping is the standard industrial process used for removal of ammonia from coking liquors and petroleum refinery sour water. Sufficient alkalinity must be available in the retort water to allow conversion of $\mathrm{NH}_{4}^{+}$ion to volatile $\mathrm{NH}_{3}$ which is stripped by the steam passing countercurrently to the water in the stripping column. Alkalinity and ammonia 
data on only one retort water, Utah in situ test, site indicate sufficient alkalinity to steam strip the ammonia. Addition of alkalinity would probably be required for the other retort waters. The total alkalinity reported for these waters carnot be considered an accurate guide, however, since the end point pH for alkalinity titration may be well below pH 7 . Ammonia stripping efficiency has not been adequately defined to date for assessing this aspect of land disposal. Furthermore, a pilot study may be required to accurately establish the optimal nitrogen loading.

It is possible that some of the organic constitutents in retort water will be resistant to oxidation and might eventually be leached into the groundwater causing some deterioration in the quality of the groundwater. A low BOD relative to a COD would indicate a large fraction of the organic matter in the retort water is not readily biodegradable. Therefore, it is anticipated that low loading rates will be required to allow sufficient time for oxidation of the organics by the biota in the soil. The generally high organic content would appear to be the limiting factor on application rates of retort water to land rather than hydraulic characteristics.

Other toxic substances which may be found in retort water include specific ions and toxic organic compounds. A limited amount of data is available on specific ions in retort water and those of concern in irrigation waters are listed in Table 3 along with recommended and estimated limits for waters used up to 20 years on fine-textured soils of $\mathrm{pH} 6.0$ to 8.5 at application rates of 37 and $99 \mathrm{~cm} /$ hectare/yr. These application rates are in the range of 25 to $99 \mathrm{~cm} /$ hectare/yr recommended for domestic wastes (5) which are much lower in organic matter than retort waters. It is likely that lower application rates would be used for high organic strength wastes such as retort water. The data in Table 3 indicate that A1, B (boron), Cu, Mo, and $Z n$ could potentially cause problems with land disposal of retort water. No data are available on the presence of organic substances which may cause problems. 
TABLE 3. Recommended Limits of Specific Ions in Irrigation Water Compared with Those Found in Retort waters from Simulated In Situ Retort at the Laramie Energy Technology Center

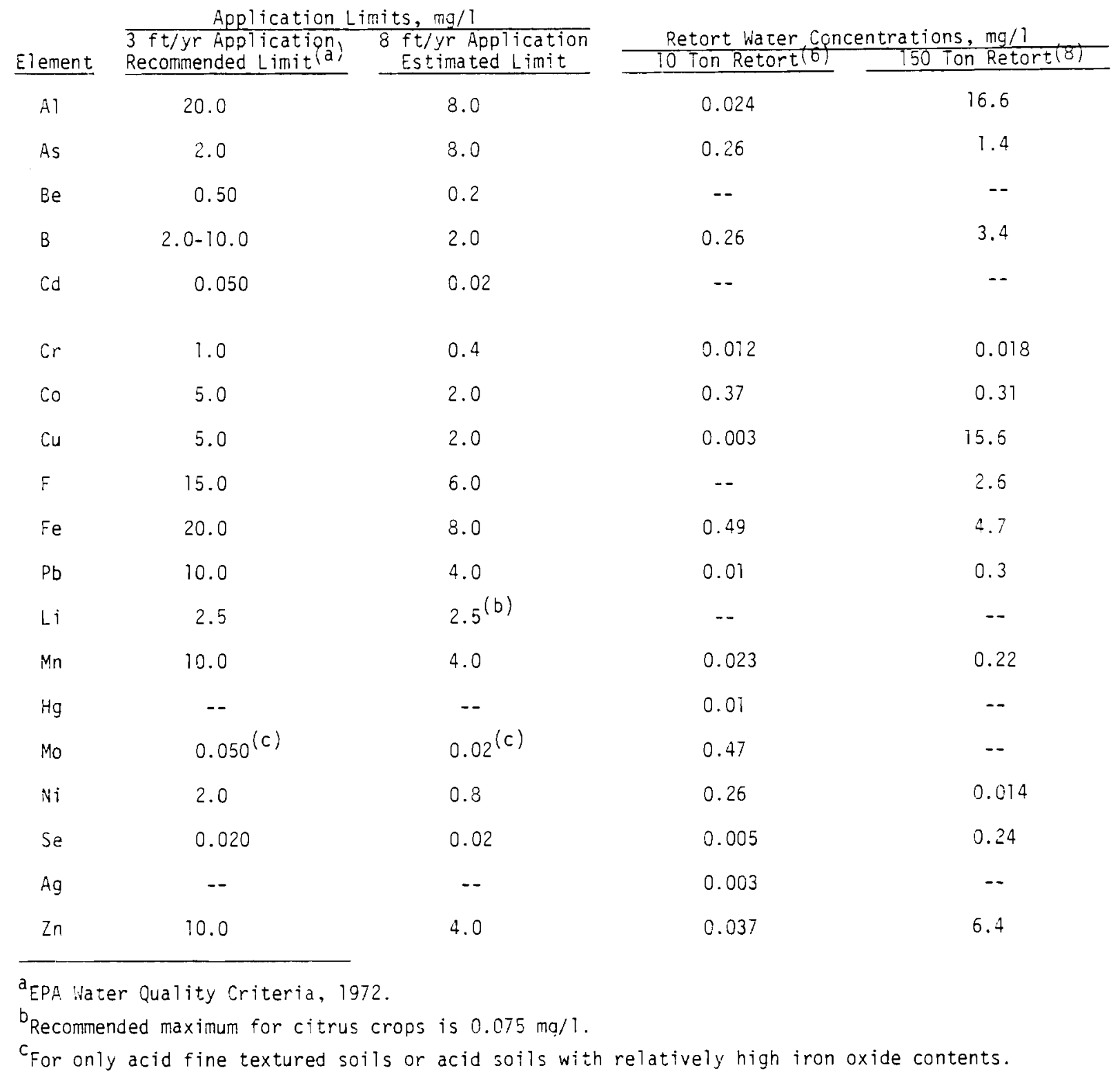


In view of the high COD concentrations in retort water, in relation to the BOD, there is a high probability that reiractory organics exist in this waste. No information is presently available on identification of these organics and their respective sorption characteristics on soil.

Substances which cause plugging of the soil commonly include sodium ion (when it is unbalanced with $\mathrm{Ca}^{+2}$ and $\mathrm{Mg}^{+2}$ ) and suspended solids (nonbiodegradable). Suspended solids can plug the pores of the soil through the process of filtration, while sodium ion can cause dispersal of the clay particles in the soil thus sealing the pore structure. Currently, data are insufficient to evaluate the possible effect of suspended solids in retort water on land disposal, but at least part of the suspended matter in retort water is expected to be removed in the pretreatment steps for ammonia stripping to avoid fouling the stripping column.

Dispersal and subsequent swelling of clay particles in the soil result when $\mathrm{Na}^{+}$becomes the predominant cation on the ion exchange sites in the clay structure. To avoid this occurrence, sufficient $\mathrm{Ca}^{+2}$ and/or $\mathrm{Mg}^{+2}$ should be present in the water to maintain the proper balance of $\mathrm{Ca}^{+2}$ and $\mathrm{Mg}^{+2}$ on the clay ion exchange sites. This balance is defined as the sodium adsorption ratio (SAR) which is computed as follows:

$$
\mathrm{SAR}=\sqrt{\frac{\mathrm{Ca}^{+2}+\mathrm{Mg}^{+}}{2}}
$$

$\mathrm{Na}^{+}, \mathrm{Ca}^{+2}$, and $\mathrm{Mg}^{+2}$ given in meq/1.

The relationship between SAR and salinity is given in Figure 1. All of the retort waters 1 isted in Table 2, for which sufficient salinity are available, have conductivity values exceeding the 2250 umhos/cm limit for irrigation of cover crops. Although it may be possible to use highly saltresistant vegetation as cover crops for land disposal of wastewater, the potential for groundwater contamination would have to be considered. 


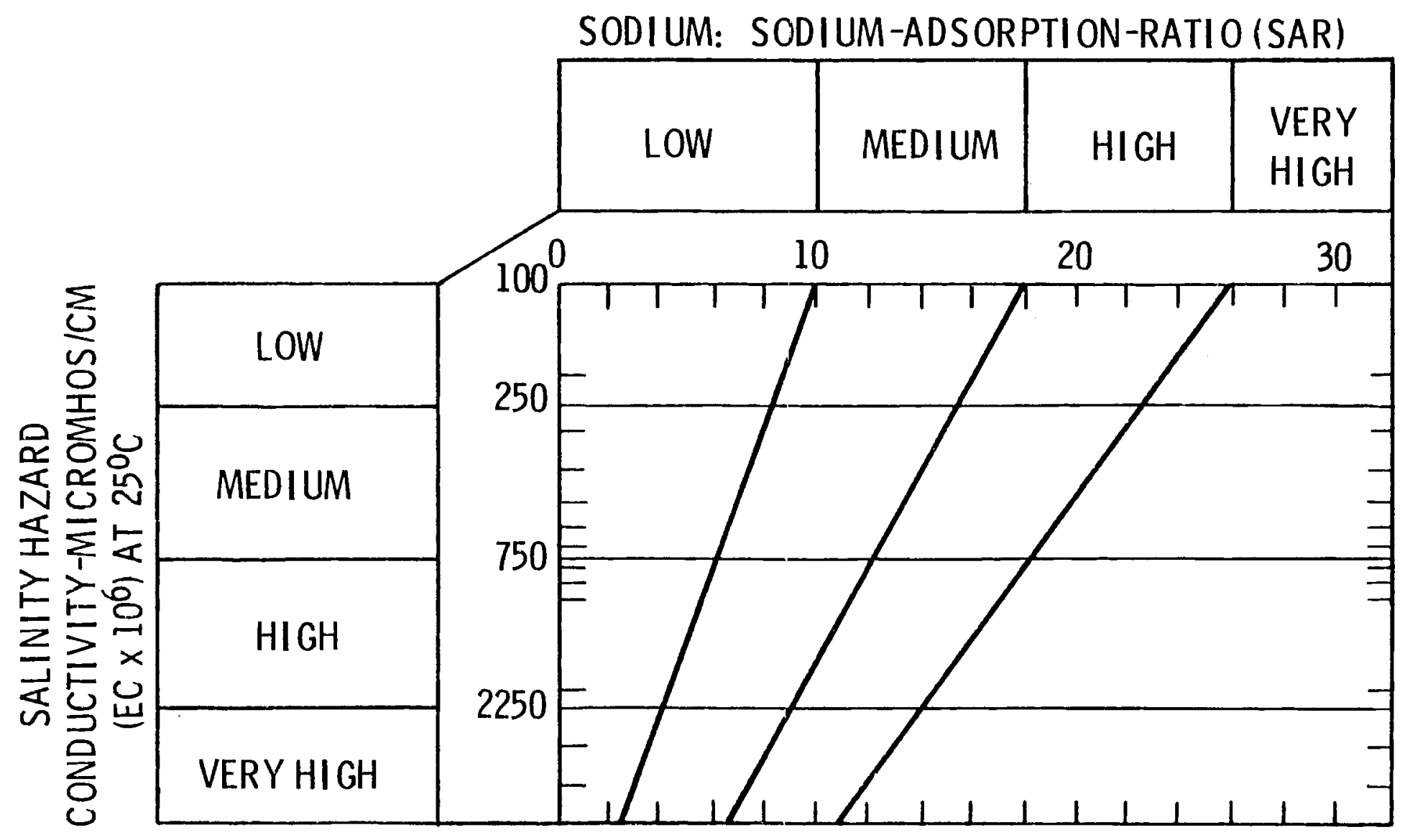

FIGURE 1. Sodium and Salinity Hazard $(9)$ 
UNDERGROIJND INUECTION

Underground or deep well injection is a disposal method which seeks to isolate a liquid waste in a geologic strata to eliminate, as nearly as possible, any environmental impacts resulting from disposal of the waste. Geologic strata selected to receive wastes by this method are generally located at a considerabie distance from ground surface to provide additional assurance of confinement and avoid contaminating freshwater aquifers near the surface. Underground injection is normally reserved for wastewaters which are very difficult or expensive to treat for release to surface receiving waters. It is used extensively for the disposal of $0 i 1$ weil brine wastes.

UNDERGROUND INJECTION WELL

A typical well consists of several pipes as illustrated in Figure 2. The function of each of the pipes is as follows:

Conductor Pipe - This is the first of several concentric pipes that are placed into a disposal we11. It extends between 30 and $60 \mathrm{~m}$ below the surface and prevents shallow water contamination while the surface hole is being drilled. This pipe is usualiy driven into place with a pile driver.

Surface Casing - This pipe extends from the surface to approximately $60 \mathrm{~m}$ below the base of the freshwater. This casing is cemented in place back to the ground level and inside the conductor pipe. Its function is to prevent the degradation of any freshwater sands.

Protection Casing - This pipe extends from the surface to a point just above or below the disposal zone, depending upon the type of completion intended. This casing is also cemented back to the surface and inside the surface casing. Its purpose is to seal off the formation above the disposal zone and below the freshwater.

Injection Tubing - This pipe is the conduit through which the effluent travels to the disposal zone. It is always sealed at the well head and usualiy just above the disposal zone. The annular space between the protecting casing 


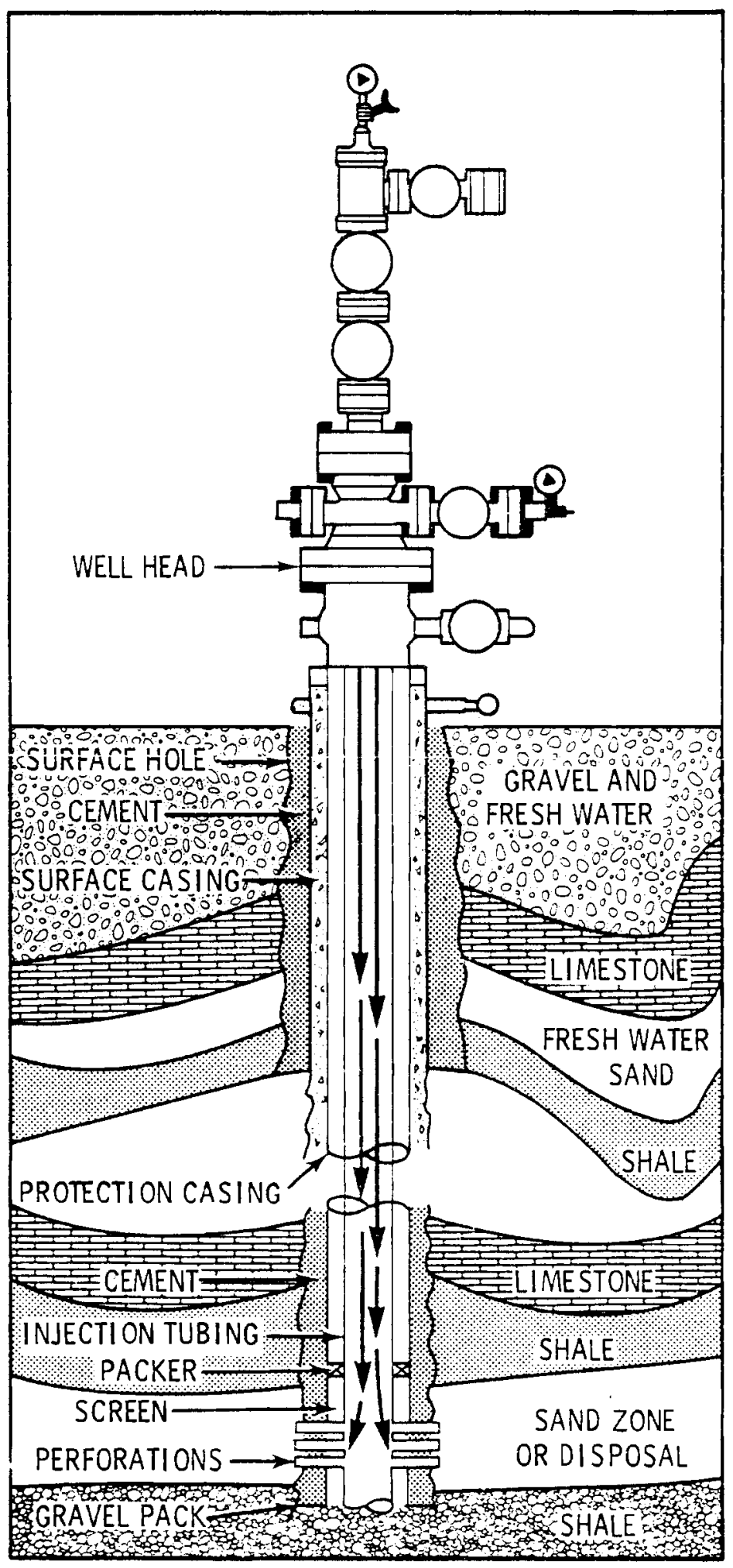

FIGURE 2. Disposal $/ 01 !^{(10)}$ 
and injection tubing is filled with a noncorrosive fiuid. Pressure should be applied to this annulus approximately $35,000 \mathrm{~kg} / \mathrm{m}^{2}$ higher than the injection pressure. The higher annular pressure will prevent any flow of effluent into the casing tubing annulus.

\section{Disposal Zone Completion}

If the well is completed in a sand formation, the gravel packed sand screen completion method should be used. If the well is completed in a 1 imestone formation, open hole or perforated completions are acceptable.

\section{WASTE CHARACTERISTICS}

The suitability of waste for underground injection depends on its volume and physical and chemical characteristics, and on the physical and chemical properties of the potential injection zones and their interstitial fluids. Wastewater that is desirable for injection must be: 1) low in volume and high in concentration, 2) difficult to treat by surface methods, 3) free of any adverse reaction with the formation fluid or the strata, 4) free of suspended solids, 5) biologically inactive, and 6) noncorrosive. $(11,12)$

Waste disposal into underground aquifers constitutes the use of limited storage space, and only concentrated, very objectionable, relatively untreatable wastes should be considered for injection. The fluids injected into deep aquifers do not occupy empty pores, but displace the fluids which saturate the storage zone. Consequentiy, optimal use of the underground storage space will be realized by the use of underground injection only when more satisfactory alternative methods of waste treatment and disposal are not available.

Reaction of the wastewater with the formation water or the strata is important. Resulting problems could include dissolving the formation, generating a gas or precipitate in the formation, and clogging by biological growths. Walker and Stewart ${ }^{(13)}$ suggest a laboratory test to ensure compatibility of the wastewater with the formation. The wastewater can be mixed in a beaker with a formation water sample and held at formation 
temperature to see if there is any precipitate or adverse reaction. Pumping the wastewater through a core sample can reveal possible clogging problems. The wastewater should be free of suspended solids and biologically inactive to avoid reservoir clogging. The corrosiveness of the wastewater should be low to prevent tubing and pump corrosion.

Retort water characteristics vary depending on the type of oil sha?e, retorting process and retort operating conditions. As shown in Table $2, \mathrm{BOD}_{5}$ values range from 350 to $5500 \mathrm{mg} / \mathrm{l}$ and $f i l$ terable residue from 150 to $101,000 \mathrm{mg} / 1$. Ultrafiltration may be necessary to remove the suspended solids. Biocide addition may be necessary because high BOD concentrations promote biological activity.

Ammonia concentration of retort water varies from 2600 to $31,500 \mathrm{mg} / 1$. Toxic level of ammonia for anaerobic fermentation is $>1275 \mathrm{mg} / 7^{(14)}$ (toxic level may vary considerably due to synergistic or antagonistic effects of other ions). High ammonia concentration in the retort water should prevent biological activity. When ammonia concentration is reduced, (either by treatment for ammonia recovery or by ion exchange during migration of fluid in the disposal zone) the probability of biological activity is increased. If necessary nutrients (mainly $\mathrm{Ca}, \mathrm{Mg}$ and $\mathrm{P}$ ) are present in the disposal zone, biological activity of the retort water is almost certain. Plugging of the injection zone by bacterial growth and by gas formation $\left(\mathrm{CH}_{4}\right.$ and $\left.\mathrm{CO}_{2}\right)$ is likely to occur unless very long residence times in the injection zone are permitted for further reaction.

\section{DISPOSAL SITE SELECTION}

Great care must be exercised in the selection of an underground disposal site for liquid wastes. (15-18) The suitability of a specific location of a waste injection well must be evaluated by a detailed geological subsurface investigation. However, regional geological conditions can be used to evaluate general suitability of certain areas. 
The regional favorability map (Figure 3 ) indicates that certain areas of the continental United States, such as the Rocky Mountains, are generaliy unsuitable for waste injection wells because igneous or metamorphic rocks lie at or near the ground surface. Such rocks do not have sufficiently high porosity or permeability to warrant their use as a disposal formation. Areas with extensive extrusive volcanic sequences exposed are also not suitable for waste disposal wells. Even though these rocks have porous zones, they usualiy contain freshwater. The waste disposal potentials of the Basin and Range Provinces (see angled lines on map) are largely unknown because the geologic conditions are complex.

The final appraisal of a disposal well site is usualiy determined by a two-phase geologic investigation. The first phase includes an evaluation of potential sites on the basis of available data. The second phase consists of a more detailed evaluation of subsurface conditions based on information obtained from drilling a pilot hole or the injection well.

Information sought during the first phase of the investigation and prior to the installation of an injection well includes the extent, thickness, depth, porosity, permeability, temperature, water quality, and piezometric pressure of potential injection zones. The presence of impermeable confining beds, lateral changes in rock properties, the existence of fauts or joints, and the occurrence of any mineral resource in the area must also be evaluated. Existing welis in the area which may penetrate the potential injection zones must be located because liquid wastes could escape through these wells if not properly plugged.

The second phase of the investigation is conducted during the drilling and testing of the injection we11. Often the actual injection zone is not selected until the well has been drilled and a number of potential zones have been tested and until the chemical quality of water in the potential zones has been evaluated. Pumping tests are used to measure the permeability and water samples are obtained for chemical analysis. Other important rock properties are measured by geophysical logging, drili-stem testing tools, or 


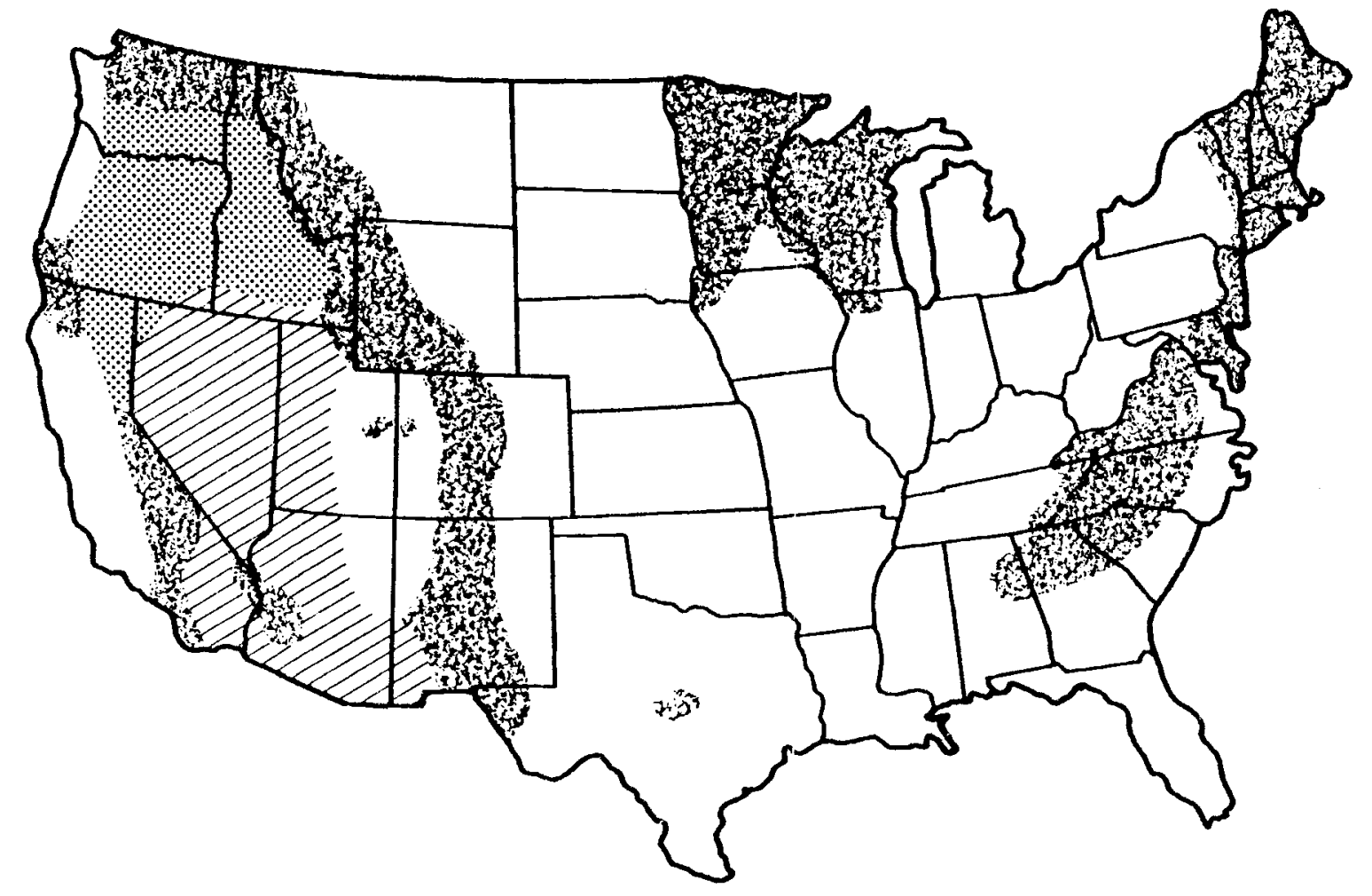

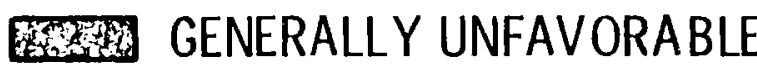
(INTRUSIVE IGNEOUS OR METAMORPHIC ROCKSI

$\square$ GENERALLY FAVORABLE
GENERALLY UNFAVORABLE (EXTRUSIVE VOLCANICS)

$2 \geq$ GENERAL FAVORABILITY UNKNOWN

FIGURE 3. Deep Well Disposal Sites (17) 
by laboratory tests on core samples. The results of these geologic investigations are usedrnot only in evaluating the feasibility of subsurface waste disposal but also to provide basic data for designing the injection well and the optimal rate of injection. Wastes may have different requirements relating to their extent of horizontal and vertical travel with time. For example, a chemically stable dilute waste may require only injection into, and dispersion in, a body of rapidly circulating groundwater that is recharged continualiy. However, a biochemically unstable effluent may require a residence time within the injection zone to permit further reaction. As an example, a very concentrated waste may require a long residence time without dispersion. To help in the selection of zones, the following classification system has been proposed.

- Zone of Rapid Circulation

The zone of rapid circulation extends from the land surface downward some tens or few hundreds of feet. Injection into this zone is normaily preciuded.

- Zone of Delayed Circulation

This zone is generally composed of freshwater which circulated continualily and freely, but is retarded sufficiently that residence time varies from several to many decades or even a few centuries. Certain innocuous wastewaters have been injected into this zone successfully with suitable monitoring.

- Subzone of Lethargic Flow

In this subzone the native liquid is commonly saline and has very low movement measured in hundreds or even thousands of years. This subzone of lethargic flow is a primary zone for potential storage of the more concentrated wastes.

- Stagnant Subzones

These subzones are, with few exceptions, several thousand feet below land surface and the fluid is hydrodynamically trapped. This zone would seem ideal for injection of very toxic wastes. However, the capability to accept and retain injected fluids needs to be assessed with extreme caution. 
- Dry Subzones

A common type of dry subzone would be a salt bed or dome in which free water is virtually nonexistent and which may be impermeable in a finite sense. Waste injected into such a zone would be wholly isolated from natural hydrodynamic circulation. However, since movement could occur through hydrofractures, performance of a dry subzone under injection should be assessed cautiously.

WELL OPERATION AND MONITORING

The operation of a disposal well should be closely controlled. Continuous monitoring of the injection pressure and flow should be made and checked for unusual variations. The annular pressure should also be monitored for variance. Biocides may have to be added to the wastes to prevent growths in the reservoir. To prevent operating problems, it is recommended to test the wastewater and annular fluid periodically for any change in composition. A uniform injection rate is more desirable than a widely varying or intermittent flow. Table 4 gives the relationship of injection pressure to well operation problems. Recommended disposal zone pressures are below $(0.6$ to $0.8 \mathrm{psi} / \mathrm{ft})$ 420 to $560 \mathrm{~kg} / \mathrm{m}^{2}$ of depth and below $75 \%$ of the critical input pressure. (19)

The critical input pressure is determined by conducting pumping tests in the well and plotting a curve of pressure versus flow rate. The point at which a sharp change in slope occurs is termed the critical input pressure (see Figure 4). This is taken to be the point at which hydraulic fracturing occurs.

\section{ECONOMICS}

Cost can determine the feasibility of underground injection as a waste disposal method. Cost of constructing and oeprating injection wells is determined largely by geologic factors.

Geologic parameters that affect constructing costs are well depth, drilling characteristics of the rock sequence, and nature of the injection 


\section{TABLE 4. Problems Relative to Monitoring a Waste Infection Project}

\section{Nature of Problem}

High Injection Rates and Low Pressures at Outset

High Injection Rates and Low Pressures Occurring Suddenly During Operations

Low Injection Rates and High Pressures at Outset
1. Leak developed in system.

2. Wastes attacking formation, increasing permeability or breaching reservoir.

1. Interaction of wastes with rock matrix or natural fluid.

2. Performance wrongly predicted.

Declining Injection Rate and Increasing Pressures

1. Solids plugging formation.
Preventive Design

1. Use effective materials specifying adequate safety margins.

2. Require whole-core analys is and more datum points, especially in questionable formations.

1. Anticorrosive materials and cathodic protection.

2. pH adjustment and pressure 1 inits.

1. Adequate geochemical data.

2. Adecuate data for accurate prediction of reservoir geometry, porosity, and permeability.

2. Precipitation in formation through interaction of wastes, rock and natural fluids.

3. Naturally expected occurrence.
1. Filtration of chemical, tiological, and stabilization treatment.

2. Reassessment of waste trea tment.

3. None.
Preventive Operations

Shutdown or slowdown until diagnosed. Back pressure on annulus of injection wells, if appropriate.

1. Locate leak and correct.

2. Alter waste treatment

to optimize. A breached reservoir may have to be abandoned.

1. Treat wastes.

2. None.
1. Flush bore hole or stimulate.

2. Abandon project when pressure exceeds limits. 


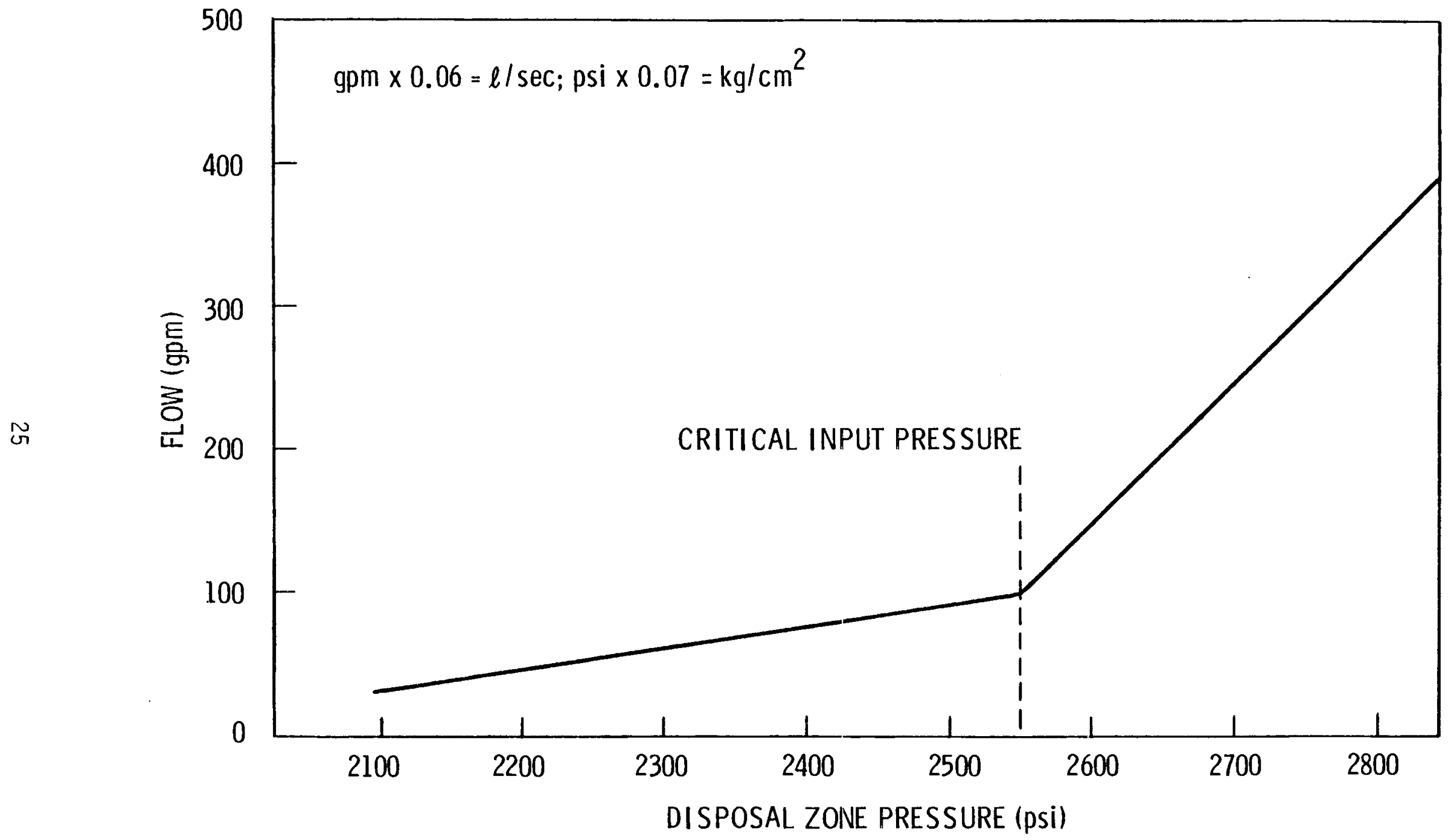

FIGURE 4. A Pressure-Flow Test of a Deep-Well 
zone. Geologic parameters that affect operating costs are permeability, porosity, and the thickness of the injection zones and fluid pressure in the reservoir, all of which determine the injection rate and operating pressure. Mineralogy and chemistry of the aquifer minerals and fluids also influence the costs since they may determine the preinjection waste treatment that is necessary.

Costs of injection well construction and operation were analyzed by Koenig $(20)$ and was concluded that the greatest influence on costs was the injection capacity of a well. Well depth and operating pressure were the next two cost influential parameters.

\section{LEGAL CONSIDERATIONS}

The 1972 Water Pollution Control Act specified that EPA should cooperate with federal, state and local agencies and industries to develop comprehensive programs to prevent or eliminate groundwater contamination and to improve sanitary conditions of these waters. In 1974, EPA issued "Administrator's Decision Statement No. 5" as agency policy on injection wells and subsurface emplacement of fluids by well injection. This policy was drafted to protect the subsurface from pollution or environmental hazards as a result of improper injection practices and poorly sited injection wells. Under this policy, EPA opposes the emplacement of wastes by injection without strict controls and a clear demonstration that such emplacement will not interfere with present or potential use of the subsurface environment, contaminate groundwater resources or otherwise damage the environment. EPA can require that all proposals for subsurface injection be critically evaluated to determine that the following guidelines have been met:

- All reasonable alternative measures have been explored and found less satisfactory in terms of environmental protection.

- Adequate preinjection tests have been made for predicting the fate of materials injected.

- There is conclusive technical evidence to demonstrate that such injection will not interfere with present or potential use of water resources nor result in other environmental hazards. 
- The injection system has been designed and constructed to provide maximal environmental protection.

- Provisions have been made for monitoring both the injection operation and the resulting effects on the environment.

- Contingency plans that will prevent any environmental degradation have been prepared to cope with all well shut-ins or well failures.

- Provisions will be made for plugging injection wells when abandoned and for monitoring plugs to ensure their adequacy in providing continuous environmental protection. Also under this policy, EPA acknowledges that subsurface injection of wastes is only a temporary means of disposal until new technology that witl ensure a higher degree of environmental protection becomes available.

In December of 1974, the National Safe Drinking Water Act was passed by Congress. The purpose of this legislation was to assure that water supply systems meet minimum national standards for the protection of public health. The Act was designed to achieve uniform safety and quality of drinking water in the nation by identifying contaminants and establishing maximum levels of acceptability. The major provision of the Act that encompasses the underground injection program is the establishment of regulations to protect the underground drinking water sources by the control of subsurface injection.

Various states are to have enforcement responsibility for groundwater protection. If a state underground injection control program is to be approved by EPA, it must:

- include minimum requirements to prevent underground injections that would endanger drinking water supplies

- prohibit injection after December 17, 1978, unless by permit

- allow permits for underground injection only when the applicant can prove that injection will not endanger drinking water sources

- provide for inspection, monitoring, record keeping, and reporting to EPA

- include no requirements that interfere with underground water or brine injection in $0 i 1$ or gas production, or for secondary or tertiary cil recovery, so long as freshwater aquifers are unaffected. 
If a state does not have an approved underground injection control program, EPA should assume enforcement responsibilities.

In August 1976, EPA issued the proposed new 40 CFR Part 146 setting forth the regulations governing state underground injection control (UIC) programs. The intent of this proposed regulation is to:

- establish minimum requirements for effective state programs to protect existing potential underground sources of drinking water from being endangered by the underground injection of fluids

- provide improved protection of public health by controlling certain potential sources of underground drinking water contamination.

- provide minimal national control

- allow a state to exercise maximum flexibility to develop programs to meet their needs, noting that differences exist between states, including geological conditions, use and availability of groundwater, and intensity of underground injection operations

- provide a program that would not be excessively costly to the states or to most injectors. 


\section{REFERENCES}

1. Federal Water Pollution Control Act, PL 92-500, October 18, 1972.

2. U.S. Department of the Interior. "Regional Impacts of 0il Shale Development," Final Environmental Statement for the Prototype 0il-Shale Leasing Program. VoT. I, 1973.

3. Reed, S., et a1. Wastewater Management by Disposal on the Land, Cold Regions Research and Engineering Laboratory, Corps of Engineers, May 1972.

4. Wallace, A. T. "Land Disposal of Liquid Industrial Wastes," Land Treatment and Disposal of Municipal and Industrial Wastewaters, Sanks, R. L., Asano, Asano, T., pp. 147-162, 1976.

5. Sanks, R. L., Asano, T. and A. H. Ferguson. "Engineering Investigations for Land Treatment and Disposal," Land Treatment and Disposal of Municipal and Industrial Wastewater, Sanks, R. L., Asano, T., pp. 1-16, 1976.

6. Jackson, L. P., R. E. Paulson, T. J. Spedding, T. E. Philitips and H. B. Jensen. "Characteristics and Possible Roles of Various Haters Significant to the In Situ 0il Shale Processing," Quarterly of Colorado School of Mines, Vol. 70, No. 4, Golden, CO, School of Mines, 1975.

7. Linstedt, K. D., E. R. Bennett and B. Harding. Characterization and Treatment of Retort Water from In Situ 0 il Shale Processing. Final Report PL 61683 for Laramie Research Center, U.S. Energy Research and Development Administration, Laramie, WY, September 1976.

8. Ossio, E. A., J. P. Fox, J. F. Thomas, and R. E. Paulson. "Anaerobic Fermentantion of Simulated In-Situ 0il Shale Retort Water," Paper presented at National Meeting of the American Chemical Society, Anaheim, CA, March 12-17, 1978.

9. Environmental Protection Agency. "Land Treatment of Municipal Wastewater Effluents--Design Factors II," EPA Technology Transfer Seminar Publication, January 1976.

10. David, K. E. and R. RR. J. Funk. "Subsurface Disposal of Industrial wastes," Industrial Water Engineering, Vol. 11, p. 16, 1974.

11. Tofflemine, T. J. and G. P. Brezner. "Deep-Well Injection of Wastewater," J. Water Pollution Control Fed., Vol. 43, p. 1473, 1971.

12. Warner, D. L. "Subsurface Disposal of Liquid Industrial Wastes by DeepWe11 Injection," American Assoc. of Petroleum Geologists Memoir. \#10, p. $16,1968$. 
13. Walker, W. R. and R. C. Stewart, "Deep Well Disposal of Waste," J. Sanitary Eng. Div., Proc. American Soc. Civil Engr, Vol. 94, p. 945, 1968.

14. McCarty, P. L. I. J. Kugelman, and A. W. Lawrence, "Ion Effects in Anaerobic Digestion," Stanford University Technical Report, No. 33, 1964.

15. National Industrial Pollution Control Council. Waste Disposal in Deep Wells, Government Publication 55-95, 34 p., February 1971.

16. Heikard, J. Deep Well Injection of Liquid Wastes, Engineering Bulletin No. 35, Dames and Moore, Los Angeles, CA, 1970.

17. Anonymous. "Deep Well Injection is Effective for Waste Disposal," Envir. Sci. and Tech., 2, pp. 406-409, 1968.

18. Dettinger, R. S., et al. Recommended Methods of Reduction Neutralization, Recovery or Disposal of Hazardous Wastes, Vol. III, Report PB 224582 , Springfield, VA, Nat. Tech. Information Service, August 1973.

19. "Conference Minutes," Deep We11 Injection Conf., New York State Department of Health, Albany, 7350 .

20. Koenig, L. "Ultimate Disposal of Advanced-Treatment Waste, Part 1, Injection," U.S. Public Health Service Publication, No. 999-W-10, AWTR-8, p. 3-83, 1964. 


\section{ACKNOWLEDGMENTS}

The authors wish to express their gratitude to Dr. A. J. Rothman of the Lawrence Livermore Laboratory who supplied samples of retort water for analysis. 
,

$=$ 


\section{APPENDIX}

REVIEW OF TECHNOLOGY FOR LAND DISPOSAL OF WASTEWATER 
APPENDIX

\section{REVIEW OF TECHNOLOGY FOR LAND DISPOSAL OF WASTEWATER}

\section{TREATMENT PROCESSES}

Removal of wastewater constitutents is accomplished by physical, chemical and biological processes.

Mechanisms

Interactions between the three processes are complex and numerous, depending on many variables. Choice of the most applicable treatment method depends on an understanding of these mechanisms and their strengths and limitations.

Microorganisms and suspended particles of wastewater are removed by the physical process of filtration. Vegetation, micro-organisms and the soil interact to retain wastewater constituents. $(1,2)$ The density of the vegetative cover and its root system provides a filter. As wastewater passes through the vegetative cover and soil system the solids are removed from the water as physical barriers are reached which cannot be passed. The texture of the soil (i.e., its proportions of sand, silt and clay) determines the amount of water it can hold. Particle sizes affect both structure, which is the manner in which soil particles are assembled, and porosity which is the total volume of space between grains in a unit volume of soil. Pore spaces are interconnected within the soil and continuous with the outer atmosphere. Generally, coarse-textured soils have high bulk density values and low porosities. On the other hand, fine-textured soils have large pore space volumes and low bulk densities. (3)

Care must be taken to avoid overloading the system which prevents further infiltration of the applied wastewater. $(4,5)$ The soil can become clogged and the formation of shallow ponds can occur resulting in anaerobic conditions. Anaerobic bacteria can create slimes of incompletely degraded organic matter and particulates which are effective soil surface sealants. 
Other factors that can cause clogging are: 1) compaction from heavy weight 2) the movement of fine grains of soil down from the upper zones, and 3) the formation of insoluble compounds from reactions between wastewater constituents and soil water and/or minerals.

Soil and root microorganisms are responsible for the biological degradation of numerous wastewater constitutuents. $(6-11)$ Both organic compounds and inorganic ions are broken down and/or utilized as energy sources for the microorganisms. These absorption and incorporation processes remove many nutrients and are capable of converting unavailable forms of some elements to forms available for plant and other microorganism metabolism. Soil parameters of pH, aeration, water, and nutrient concentrations influence the composition of the soil fauna depending upon the requirements of the microorganisms. Addition of wastewater constituents, for example, nitrogen, must be made in a manner which prevents accumulation of toxic concentrations to plant and animal systems, overloading and leaching of constituents (in this case, nitrates into receiving waters) or depletion of the oxygen supply if aerobic conditions are desirable.

Chemical reactions occurring within the soil system then remove wastewater constituents. Microorganisms interact in the soil solution at the soil particle surface and at root surfaces. The major processes that occur include ion exchange, oxidation and reduction, and precipitation of insoluble compounds. Of soluble salts in the soil, $\mathrm{Ca}^{2+}, \mathrm{Mg}^{2+}, \mathrm{Na}^{+}, \mathrm{Cl}^{-}, \mathrm{SO}_{4}{ }^{2-}$, and $\mathrm{HCO}_{3}{ }^{-}$are the major ions. Other ions are $\mathrm{Al}^{3+}, \mathrm{K}^{+}, \mathrm{CO}_{3}{ }^{2-}$, and $\mathrm{NO}_{3}{ }^{-}$. Chemical bonding is influenced by the ion's valence as well as the charge density of the solid phase. Precipitates formed are primarily carbonates, oxides, and hydroxides of aluminum, calcium, iron, and magnesium. Precipitation of $\mathrm{Cu}, \mathrm{Zn}, \mathrm{Mn}$, and $\mathrm{Fe}$ is the mechanism primarily responsible for their removal. Oxidationreduction reactions convert constituents into forms that are exchangeable, chemically available for plant and microorganism use, or capable of forming insoluble compounds. $(3,12-14)$ 
Land Application Methods

Existing land treatment facilities can be classified according to two different basic design patterns based on differences in liquid loading rates, 7 and area requirements, and the interaction of the wastewater with vegetation and soil. The first method, infiltration uses soil as purification medium while the second overland flow, uses the land surface as the purification medium. Infiltration is further divided into two categories, irrigation and infiltration-percolation, which involve different rates of application. (15) A synopsis of the characteristics and requirements of these processes is given in Table A-l.

Irrigation is the most common method of wastewater application. Its objectives are to support plant growth and to treat the effluent. In areas where irrigation water is scarce, the system is managed to provide the maximum return from a crop, whereas in areas of sufficient water supply, criteria allowing maximum hydraulic loading are foilowed. (5) Revenue realized from a crop is used to defray operating costs so deciding whether the system is to produce crops or treat effluent is important. Controlling soil salts is vital for plant growth to prevent buildup of toxic concentrations. This is accomplished by managing the wastewater salt concentrations and the rates of application. For instance, most wastewaters applied to the 1 and have been pretreated to prevent overloading of the soil system and permit compliance with discharge limits. Effluents with high $\mathrm{BOD}, \mathrm{Na}$, and/or $\mathrm{NO}_{3}-\mathrm{N}$ values are most suitable for pretreatment. Some effluents undergo treatment as resources are recovered. Pretreatment also helps equalize wastewaters to provide a more uniform solution for application. $(2,16)$

Consideration of topography, soil conditions, weather conditions, and economics determines the irrigation technique to be used. Figure A-1 illustrates the different irrigation techniques. Spraying, ridge and furrow, and flooding techniques vary in their efficiency, costs, flexibility, uniformity of distribution, and problems. Spray irrigation is the most common of the land treatment methods for both municipal and industrial wastewaters because it is adaptable to varying crops, topography, climate, and other design criteria. $(17,18)$ 


\section{TABLE A-1. Assumed Model Disposal Conditions and Characteristics for Land Applications of Wastewaters $(2,5)$}

\begin{tabular}{|c|c|c|c|}
\hline Item & Irrigation & Overland Flow & Infiltration-Percolation \\
\hline Soil type & $\begin{array}{l}\text { iledium texture soils, } \\
\text { silt loam. }\end{array}$ & Clay, clay loam. & $\begin{array}{l}\text { Loamy sand to sandy } \\
\text { loam. }\end{array}$ \\
\hline $\begin{array}{l}\text { Permeability of the } \\
\text { most impermeable sub- } \\
\text { soil horizon to } 60 \\
\text { in. }(1.5 \mathrm{~m}) \text {. }\end{array}$ & $\begin{array}{l}\text { Moderately rapid to } \\
\text { moderate; }>0.5 \mathrm{in.} \\
(1.5 \mathrm{~cm}) / \mathrm{hr} .\end{array}$ & $\begin{array}{l}\text { Yery low; <0.2 in. } \\
(0.5 \mathrm{~cm}) / \mathrm{hr} .\end{array}$ & Rapid \\
\hline Infiltration & $\begin{array}{l}\text { Moderately rapid } \\
\text { to moderate. }\end{array}$ & $\begin{array}{l}\text { Slow-very slow; } \\
<0.2 \text { in. }(0.5 \\
\mathrm{cm}) / \mathrm{hr} .\end{array}$ & $\begin{array}{l}\text { Rapid to very rapid; } \\
\geq 1 \text { in. }(5 \mathrm{~cm}) / \mathrm{hr}\end{array}$ \\
\hline Soil drainage & $\begin{array}{l}\text { Moderately well } \\
\text { drained. }\end{array}$ & Poorly drained. & Excessively drained. \\
\hline Soil Depth & $\begin{array}{l}\text { Uniformly }>5 \text { feet } \\
(1.5 \mathrm{~m})\end{array}$ & $>2$ feet $(0.6 \mathrm{M})$ & $>10$ feet $(3 \mathrm{~m})$ \\
\hline $\begin{array}{l}\text { Effective travel } \\
\text { Distance }\end{array}$ & $\begin{array}{l}\text { Preferred } 10 \text { feet } \\
(3 \mathrm{~m}) \text { or more. }\end{array}$ & $\begin{array}{l}\text { Surface travel of } \\
150 \text { feet }(46 \mathrm{~m}) \text {. }\end{array}$ & $\begin{array}{l}\text { Subsurface }>200 \\
\text { feet }(60 \mathrm{~m})\end{array}$ \\
\hline Slope & $\begin{array}{l}\text { Up to } 8 \text { feet }(2.4 \\
\text { iii). }\end{array}$ & 5 feet $(1.5 \mathrm{~m})$ & -- \\
\hline $\begin{array}{l}\text { 'Naterholding capacity } \\
\text { to } 50 \text { in. }(1.5 \mathrm{~m})^{\mathrm{a}}\end{array}$ & $>6$ in. $(15 \mathrm{~cm})$ & -- & -- \\
\hline $\begin{array}{l}\text { Depth to ground } \\
\text { water }\end{array}$ & $\begin{array}{l}>5 \text { feet }(1.5 \mathrm{~m}) \\
\text { seasonal high } \\
\text { groundwater table. }\end{array}$ & $>3$ feet $(0.9 \mathrm{~m})$ & $\begin{array}{l}15-20(4.5-6 \mathrm{~m}) \\
\text { or more. }\end{array}$ \\
\hline Vegetation & Grass, year-round. & $\begin{array}{l}\text { Permanent growing } \\
\text { grass. }\end{array}$ & Vegetated. \\
\hline Application Technique & Spray. & Spray. & Surface. \\
\hline Objective & $\begin{array}{l}\text { Maximized agricultur- } \\
\text { al production by } \\
\text { supplying irrigation } \\
\text { needs. } \\
\text { May be considered a } \\
\text { reuse option as weil } \\
\text { as advanced treatment } \\
\text { of partially treated } \\
\text { wastewater. }\end{array}$ & $\begin{array}{l}\text { Maximizes water } \\
\text { treatment. } \\
\text { Crop harvest is } \\
\text { incidental. } \\
\text { Used as secondary } \\
\text { troatment of raw } \\
\text { wastewater or ad- } \\
\text { vanced treatment } \\
\text { of secondary treated } \\
\text { wastewater. }\end{array}$ & $\begin{array}{l}\text { Maximizes water } \\
\text { filtration and per- } \\
\text { colation to ground- } \\
\text { ivater. } \\
\text { Crop production is } \\
\text { not a benefit. May } \\
\text { not be a crop. }\end{array}$ \\
\hline
\end{tabular}




\section{TABLE A-1 (Cont'd)}

\begin{tabular}{|c|c|c|c|}
\hline Item & Irrigation & Overland Flow & Infiltration-Percolation \\
\hline \multirow[t]{2}{*}{$\begin{array}{l}\text { Discersal of applied } \\
\text { water }\end{array}$} & $\begin{array}{l}\text { Most water to evapo- } \\
\text { ration. }\end{array}$ & $\begin{array}{l}\text { Most to surface run- } \\
\text { off. }\end{array}$ & $\begin{array}{l}\text { Host water percolates to } \\
\text { grouncwater. }\end{array}$ \\
\hline & $\begin{array}{l}\text { Some water to per- } \\
\text { colation and leaching } \\
\text { of salts. } \\
\text { Tailwater runoff from } \\
\text { surface irrigation } \\
\text { can be controlled. }\end{array}$ & $\begin{array}{l}\text { Some water to evapo- } \\
\text { ration and very } \\
\text { little to perco- } \\
\text { lation. }\end{array}$ & $\begin{array}{l}\text { Some water to evapotrans- } \\
\text { piration. } \\
\text { No runoff. } \\
\text { May result in buildup of } \\
\text { large groundwater mound. }\end{array}$ \\
\hline \multirow[t]{2}{*}{ Impact on quality } & $\begin{array}{l}\text { BOD and SS almost com- } \\
\text { pletely eliminated. } \\
\text { Nutrients removed by } \\
\text { crop and soil. } \\
\text { Heavy metals adsorbed } \\
\text { or precipitated. }\end{array}$ & $\begin{array}{l}\text { BOD ard SS greatiy } \\
\text { reduced. } \\
\text { High nitrogen } \\
\text { renoval. } \\
\text { Some phosphorus } \\
\text { removai. }\end{array}$ & $\begin{array}{l}\text { BOD and SS recuced. } \\
\text { Some nutrient removai } \\
\text { by soil and croo. } \\
\text { Additional salts leached } \\
\text { out of soil by excess } \\
\text { applied water (sait } \\
\text { loading). }\end{array}$ \\
\hline & $\begin{array}{l}\text { Total dissolved ionic } \\
\text { solids (TDIS) concen- } \\
\text { tration greatly } \\
\text { increased by evapo- } \\
\text { transpiration. } \\
\text { Increase in hardness } \\
\text { of percolate. }\end{array}$ & $\begin{array}{l}\text { Reduction of some } \\
\text { heavy metals. } \\
\text { Little change in } \\
\text { TDIS. }\end{array}$ & $\begin{array}{l}\text { Increase in hardness of } \\
\text { percolate. }\end{array}$ \\
\hline
\end{tabular}

\footnotetext{
Water-holding capacity in inches from the soil column is the depth of the layer of water that would be formed if all water in the soil that can be used by plants were concentratec at the soil surface.
} 


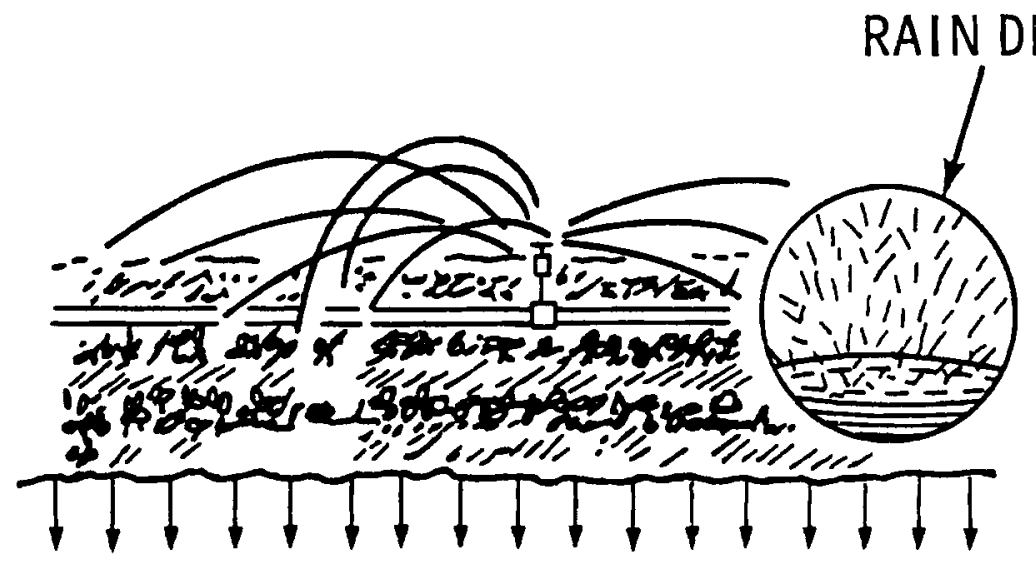

(a) SPRINKLER

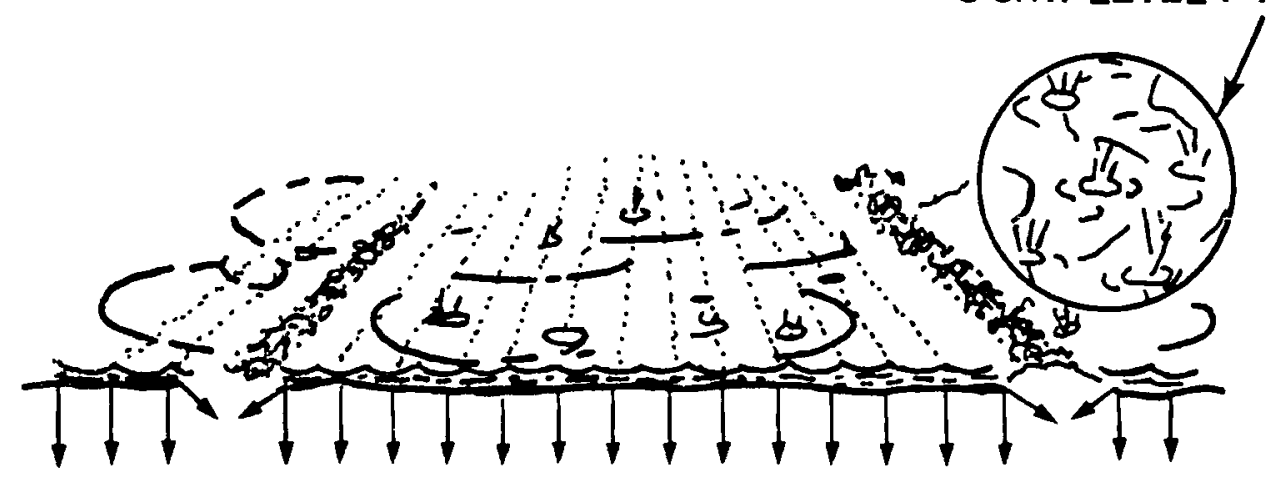

(b) FLOODING

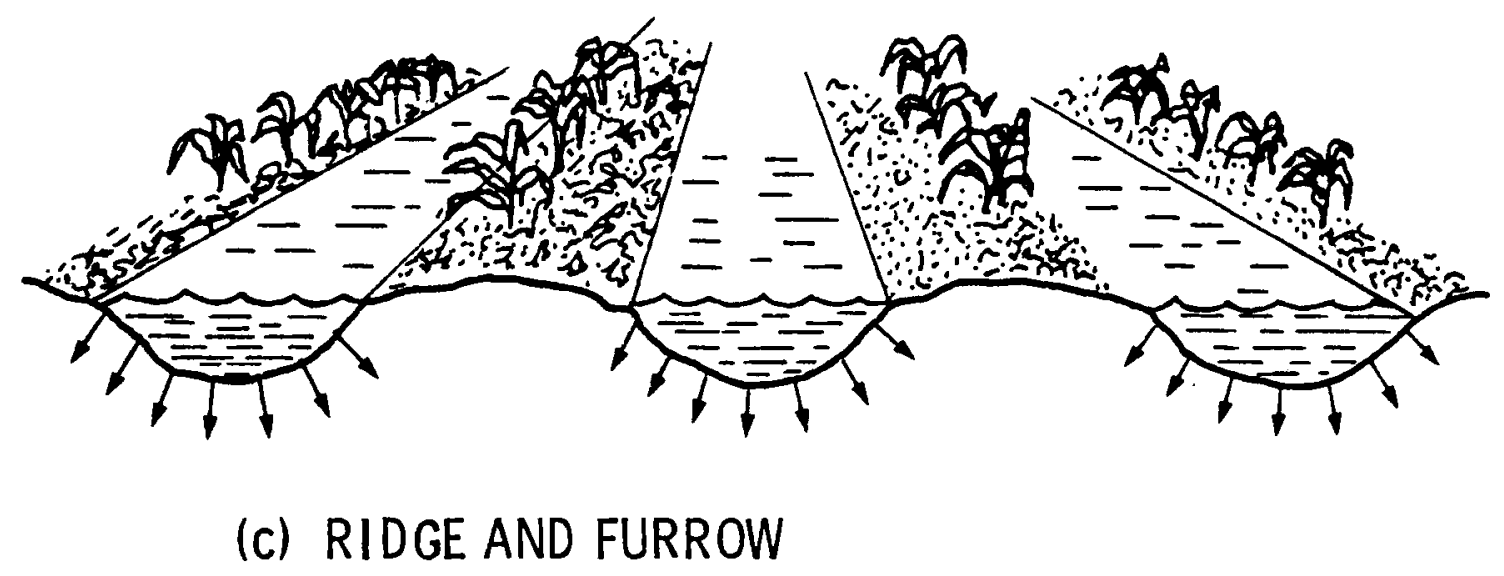

FIGURE A-1. Basic Methods of Application (15) 
When wastwater disposal is the prime consideration and the available soils have high infiltration and permeability capabilities, the infiltrationpercolation or rapid infiltration method should be considered. The high application rates lower the land requirements. In order to maintain infiltration rates and the soil oxygen level, loading cycles are carried out. Application schedules range from $8 \mathrm{hr}$ flooding and $16 \mathrm{hr}$ drying each day to flooding and drying periods of several weeks each. Infiltration-percolation renovates the water for reuse or for recharging the groundwater table; however, it does have the lowest potential for nutrient removal. Removal of BOD, suspended solids and microorganisms occurs primarily in the top meter of soil. All climates have permitted the operation of such systems with application rates being lowered in the cooler months. Most systems employ rapid-infiltration basins where the water is spread. Spraying is also used in some cases, mainly in industrial applications. A vegetative cover for protecting the soil surface from spray droplets is seldom used. Soil drainage is the major limiting factor and unless there is sufficient distance to the water table and moderately to rapidly draining soils, infiltration-percolation is not a viable method of land treatment. (19-21)

Overland flow provides an alternative treatment for use on lands with impermeable soils and gentle uniform slopes. In areas with high groundwater tables or heavy clayey soils, overland flow should be considered. In this method, wastewater is sprayed from the ridgetops, and as it runs off and flows through the dense vegetation cover, usually grass, it undergoes biological treatment and fittration. Low rates of appication maintain aerobic conditions and prevent erosion. Frequent applications reduce land requirements below those of irrigation systems while treating similar quantities. The minimum amount of pretreatment consists of grit and grease removal to avoid clogging of both irrigation and soil systems. BOD and suspended solids removal are good, while there is little change in the total dissolved ionic solids and limited phosphorus and heavy metal removal. Water is lost as a result of surface runoff, evaporation and some infiltration. Both municipal and industrial waters have been treated by this method producing effluents 
which meet discharge standards and are suitable for crop irrigation, groundwater recharge, or industrial reuse. Storage is required during colder months as the treatment mechanism is primarily biological. Harvesting the cover crop is incidental; however, it does provide additional nutrient removal. Areas with sandy soils, widely varying topography or very shallow soils are not suitable for overland flow. $(2,4,5,22)$

\section{DESIGN CONSIDERAT IONS}

Each of the above basic treatment methods are affected differently by the various design factors. Major areas to consider in designing land disposal systems include:

- wastewater quality

- environmental characteristics

- operation/maintenance considerations

- environimeritar assessment.

With the exception of wastewater quality the basic principles of design will be related to the different methods of application.

\section{Wastewater Quality}

The design of land disposal systems may be controlled either by hydraulic loading or by the concentration of one or several constituents in the wastewater. (23) The BOD concentration, for example, will usually control the design at concentration exceeding $1000 \mathrm{mg} / \mathrm{l}$. High BOD concentrations would require reduced loading rates to allow sufficient time for soil biota to aerobically decompose the organic matter contained in the wastewater. Other constituents such as nitrogen may also dictate the land requirement. The presence of high $\mathrm{Na}^{+}$concentrations relative to $\mathrm{Mg}^{+2}$ and $\mathrm{Ca}^{+2}$ can also cause problems depending on soil type. This condition can lead to conversion of clays contained in the soil from the predominantly $\mathrm{Mg}^{+2}$ and $\mathrm{Ca}^{+2}$ forms to a predominantly $\mathrm{Na}^{+}$form which swells and tends to plug the pore spaces of the soil. Toxicants in the waste can also limit the amount of wastewater that can be applied to a given area of land. It is not possible at the present time to derive a general purpose model for all industrial wastes relating 
performance to the chemical composition of the wastewater. It is therefore necessary to rely on field test plots to supply the information needed for design of the disposal system.

\section{Environmental Characteristics}

Several environmental factors influence the wastewater application method chosen for a particular area. Climate, for example, plays an important role. A system's loading rate is influenced by the amount of precipitation and the time of year that it falls; therefore, temperature and its seasonal variations must be considered. Soil microorganisms remove wastewater constituents more effectively when temperatures are in the optimal growth range. Furthermore, the length of the growing season determines the number and types of crops. Systems in which two plantings or more are grown and harvested report higher removal rates because of nutrient uptake.

Irrigation systems are limited by the length of growing season and crop water requirements. Application of wastewater has been continued in temperatures down to $25^{\circ} \mathrm{F}$ before shutdown and then resumed once the average daily temperature reaches $40^{\circ} \mathrm{F}$. Effective growing/application seasons vary from 5 to 9 months. Variations in precipitation will cause changes in the hydraulic loading to maintain the desired water balance. Overland flow systems are similar to those using irrigation in their climatic criteria. Operation is practical in wetter weather providing the increased volume does not reduce the treatment by increasing the runoff rate time significantly. Infitrationpercolation is the method least affected by extreme climates. Year-round operation using municipal wastewater has been reported with decreased loads applied under a layer of ice. $(4,5,16)$

Evapotranspiration is a consumptive water use which affect loading, and in arid regions must be accounted for in obtaining water rights. The number of days which permit wastewater appiication determines the amount of storage required. For spray irrigation systems, the spread of microorganisms and toxic substances by the wind must be considered in the design. Information on an area's climate usualiy may be obtained from the National Oceanic and Atmospheric Administration (formerly the Weather Bureau) which publishes the "Monthly Summary of Climatic Data" and "Climatic Summary of the U.S." $(4,5,21)$ 
Topography can also dictate the process and application method of land treatment. Sprinkler and surface irrigation of cultivated crops can be adapted to slopes of 15 to $20 \%$ and up to $5 \%$, respectively. Forested slopes up to $30 \%$ have been successfully spray irrigated. Infiltration-percolation is best located on flat terrain to avoid interference from lateral movement of a high basin. Overland flow requires slopes of 2 to $8 \%$ that have been smoothed to allow uniform flow of the wastewater over the sod-covered ground. Increasing slope decreases the infiltration rate; consequently, runoff causing erosion is a problem where slopes retard infiltration. Topographic maps from the U.S. Geological Survey or U.S. Soil Conservation Service, field studies or aerial photographs can provide the necessary information. $(4,5)$

The underground water system is another factor, since the flow of water is governed by the physical limits of the soil it passes through. In addition, water normally returns to the surface through a spring or other natural water bodies, or is withdrawn from a well. The quality and distance of the groundwater below the soil surface will determine which design parameters are needed to achieve effective wastewater treatment. For example, sufficient distance to the water table is needed to remove nutrients. The level of groundwater is basically determined by the rate of water applied to the surfaces in relation to the rate at which it passes through. When the application rate is greater than the permeability of the soil, the water table will rise. Should the water table reach the surface, clogging would occur and systems designed to remove water would be necessary. Therefore, in areas with very low infiltration rates, overland flow, which is designed for surface treatment, is a viable option. Infiltration-percolation requires soil depths of at least $1.5 \mathrm{~m}$ if underdrainage is provided, while a depth of $4.6 \mathrm{~m}$ is recommended for long-term use. $(4,5,20)$ Soils with depths of less than $51 \mathrm{~cm}$ to the water table are considered poorly suited to irrigation systems. As the depth to groundwater increases, the removal efficiency for a soil depending on soil type and pollution parameter increases. 
Care in applying wastewater is necessary in preventing the degradation of groundwater quality. The effect of a wastewater on the quality of the existing groundwater can be estimated using the site characteristics and the qualities of both waters. If the groundwater is an area's drinking or irrigation water source then wastewaters of high nitrogen and high total dissolved solids must be treated adequately to prevent groundwater pollution. The Safe Drinking Water Act of 1974 protects drinking water sources. Table A-2 lists EPA regulations on interim primary drinking water standards. The recommended and estimated maximum ion concentrations for irrigation water are found in Table A-3. Systems that are properly designed and managed can provide treated effluents that comply with the existing standards and protect water systems.

Finally, analyses of the available soils are necessary to determine the feasibility of land treatment. $(5,24,25)$ Design, operation and maintenance parameters depend on $\mathrm{pH}$, cation exchange capacity, classification, salinity, permeability, hydraulic capacity and pore size to remove nutrients and accept higher than normal hydraulic loadings. Soil horizons are composed of identifiable layers which react differently with water percolating through the system. Layers vary in their capacity to remove nutrients and transport water. Some soils are ideal for wastewater applications, while others may be adapted by adjusting the loading rates or altering the composition of the wastewater.

Spray irrigation requires soil capable of supporting vegetation. Loamy soils are preferred; however, sandy to clay loams will provide adequate drainage. $(5,17)$ Infiltration-percolation systems require well-drained soils, such as sands, sandy loam, loamy sand and gravels. Clays and clay loams, those soils with limited drainability due to soil particle size or water tabie level, are suitable for overland flow systems. $(2,5,21)$ Information on soils is available from site examinations, the U.S. Soil Conservation Service, and agricultural extension services. (5) 
TABLE A-2. EPA Regulations on Interim Primary Drinking Water Standards*

\begin{tabular}{|c|c|c|}
\hline Constituent or Characteristic & Value & Reason for Standard \\
\hline $\begin{array}{l}\text { Physical } \\
\text { Turbidity, units }\end{array}$ & $1^{a}$ & Aesthetic \\
\hline $\begin{array}{l}\text { Chemical, mg/l } \\
\text { Arsenic } \\
\text { Barium } \\
\text { Cadmium } \\
\text { Carbon chloroform extract } \\
\text { Chromium, hexavalent } \\
\text { Cyanide } \\
\text { Fluoride } \\
\text { Lead } \\
\text { Mercury } \\
\text { Nitrates as } \mathrm{N} \\
\text { Selenium } \\
\text { Silver }\end{array}$ & $\begin{array}{l}0.05 \\
1.0 \\
0.01 \\
0.7 \\
0.05 \\
0.2 \\
1.4-2.4 \mathrm{~b} \\
0.05 \\
0.002 \\
10 \\
0.01 \\
0.05\end{array}$ & $\begin{array}{l}\text { Toxic } \\
\text { Toxic } \\
\text { Toxic } \\
\text { Toxic } \\
\text { Toxic } \\
\text { Toxic } \\
\text { Toxic } \\
\text { Toxic } \\
\text { Toxic } \\
\text { Toxic } \\
\text { Toxic } \\
\text { Cosmetic }\end{array}$ \\
\hline $\begin{array}{l}\text { Bacteriological } \\
\text { Total coliform, per } 100 \mathrm{ml}\end{array}$ & 1 & Disease \\
\hline $\begin{array}{l}\text { Pesticides, mg/? } \\
\text { Chlordane } \\
\text { Endrin } \\
\text { Heptachlor } \\
\text { Heptachlor epoxide } \\
\text { Lindane } \\
\text { Methoxychlor } \\
\text { Toxaphene } \\
\text { 2,4-D } \\
2,4,5-T P\end{array}$ & $\begin{array}{l}0.003 \\
0.0002 \\
0.0001 \\
0.0001 \\
0.004 \\
0.1 \\
0.005 \\
0.1 \\
0.01\end{array}$ & $\begin{array}{l}\text { Toxic } \\
\text { Toxic } \\
\text { Toxic } \\
\text { Toxic } \\
\text { Toxic } \\
\text { Toxic } \\
\text { Toxic } \\
\text { Toxic } \\
\text { Toxic }\end{array}$ \\
\hline
\end{tabular}

\footnotetext{
${ }^{a}$ Five $m g / 1$ may be substituted if it can be demonstrated that it does not interfere with disinfection.

Dependent upon temperature; higher limits for lower temperatures.

*40 CFR 141.
} 
TABLE A-3. Recommended and Estimated Maximum Concentrations of Specific Ions in Irrigation Waters $(\mathrm{mg} / 1)^{5}$

For Waters Used Continuously on all Soil Element

Removal Mechanism

\section{Aluminum}

PR, S

Arsenic

Beryllium

Boron

Cadmium

Chromium

Cobalt

Copper

$\frac{D}{\omega}$

Fluoride

Iron

Lead

Lithium

Manganese

Mercury

Molybdenum

Nickel

Selenium

Silver

Zinc

PR

$A D, W$

$A D, C E, S$

$A D, C E, S$

$A D, C E, S$

$A D, C E, S$

$A D, S$

$P R, C E, S$

$A D, C E, S$

$C E, W$

$P R, C E, S$

$A D, C E, S$

$A D, S$

$A D, C E, S$

$A E, W$

$A D, C E, S$

$A D, C E, S$

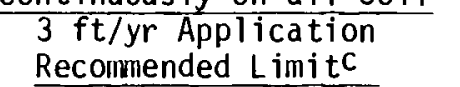

5.0

0.10

0.10

0.75

0.010

0.10

0.050

0.20

1.0

5.0

5.0

$2.5^{\mathrm{d}}$

0.20

$-$

0.010

0.20

0.020

$-$

2.0
For Waters Used up to 20 Years on

Fine Textured Soils of $\mathrm{pH} 6.0$ to $8.5^{\mathrm{a}}$

$3 \mathrm{ft} / \mathrm{yr}$ Application $8 \mathrm{ft} / \mathrm{yr}$ Application $80 \mathrm{ft} / \mathrm{yr}$ Application

Recommended Limitc Estimated Limit Estimated Limit

20.0
2.0
0.50
$2.0-10.0$
0.050
1.0
5.0
5.0
15.0
20.0
10.0
$2.5^{\mathrm{d}}$
10.0
-
$0.050^{\mathrm{e}}$
2.0
0.020
-
10.0

8.0

0.8

0.08

0.02

2.0

0.002

0.04

0.2

0.2

0.6

0.8

0.4

2.5

0.4

$-$

$0.002^{\mathrm{e}}$

0.08

0.02

$-$

0.4

a These levels will normally not adversely affect plants or soils. No data are available for mercury, silver, tin, titanium, or tungsten.

${ }^{b} \mathrm{AD}=$ adsorption with iron or aluminum hydroxide, $\mathrm{pH}$ dependent; $\mathrm{AF}=$ anion exchange; $\mathrm{CE}=\mathrm{cation}$ exchange; $\mathrm{PR}=$ precipitate, $\mathrm{pH}$ dependent-iron and manganese are also subject to changes by oxidation/reduction reactions; $S$ = strong strength of removal; $W=$ weak strength of removal.

$C_{E P A}$ Water Quality Criteria, 1972.

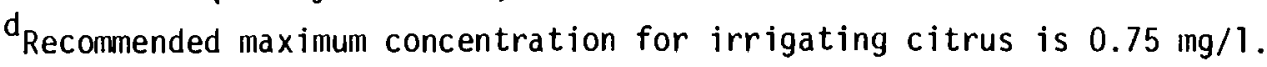

For only acid fine textured soils or acid soils with relatively high iron oxide contents. 
OPERATION AND MAINTENANCE CONSIDERATIONS

Parameters dealing with the operation and maintenance of a wastewater 1 and treatment site will vary according to the method and to the site. An area's overall land use plan will dictate a system's acceptability with the general public. As the objectives are determined and evaluated, the operation and maintenance details are incorporated to produce an efficient system capable of treating wastewater with minimum impacts on the environment. ${ }^{(26)}$ Described below are the general areas to be considered in designing a system with the most efficient and economical operation.

Locating the treatment site will depend on the availability of land, the acquisition cost, its distance from the source or treatment plant, the method of transportation, the amount of land required, and the elevation changes involved. Once the available land is selected the next choice is whether to buy or rent the land. Land requirements are set by the design application rates, the buffer zone requirements, storage space needed, and the area needed to house personnel and equipment. (27) Application rates should not overload a soil's treatment ability and depend on water, nitrogen, phosphorus, organic, and other constituent balances. (28) Hydraulic loading rates consider the amount of precipitation, evapotranspiration, percolation runoff, and effluent application. The maximum nitrogen load to maintain acceptable nitrogen levels in the soil percolate depends on crop uptake, denitrification, volatilization, wastewater load, and contribution to surface waters. ${ }^{(29)}$ A soil's capacity to oxidize $B O D$ and $C O D$ and to remove and adsorb heavy metals, ions and salts is factored into the design application rate. Storage requirements are related to the length of the operating season as determined by climate. Equalization of the wastewater is achieved by temporary storage. Storage also acts as a system backup to allow routine maintenance and emergency protection. (28)

When crops are grown, selection is based on their relationship to the critical loading parameter. Plants vary in their tolerance to factors such as salt, heavy metals, and even water. Public health regulations specify 
the types of crops grown under wastewater irrigation. The length of the growing season fayors those crops with short life cycles. Ease in cultivation and harvesting reduce operation of costs. A look at the existing vegetation will aid in predicting drainage and other soil conditions at the site. $(27,28)$

Most wastewaters must be treated prior to land application. The extent of pretreatment is dictated by the organic loading rates that the soil system can handle and the compatibility of the wastewater with the application equipment. Microorganism levels, if potentially high, are reduced by pretreatment and permit safe land application. (28)

Personnel and equipment requirement costs are part of the total system cost. The method of application chosen will determine the type of management and controls to insure efficient operation. The degree of monitoring needed to record a system's efficiency, and procedures to handle emergencies, will also affect system management options and requirements. $(26,28)$

Environmental Assessment

The impact of the project on the environment, including public health, social and economic aspects must be assessed for each land application alternative. Soils, vegetation, water and air quality, and animal life will be impacted and these must be evaluated. Potential threats to public health may develop in the underlying groundwater, from the presence of insects and rodents, in surface runoff from microorganisms in irrigation, aerosols, and from crop contamination. (30) Social impacts arise if residents must be relocated, greenbelts and open space are reduced, unique environments are included, and the growth of the community is influenced. Involvement of the public in the decision making process adds to the project acceptability. The economic impact is reflected in the local economy. Land acquisition costs, tax considerations, and the conservation of resources and energy contribute to the overall operation and maintenance of a land treatment system. 


\section{APPENDIX REFERENCES}

1. Sopper, W. E., "Renovation of Municipal Wastewater for Groundwater Recharge by the Living Filter Method," Biological Control of Water Pollution, Tourbier, J. and Pierson, R. W., Jr., editors, Univeristy of Pennsylvania Press, 1976.

2. Spyridakis, D. E. and E. B. Welch. "Treatment Processes and Environmental Impacts of Waste Effluent Disposal on Land, "Land Treatment and Disposal of Municipal and Industrial Wastewater, Sanks, R. L. and Asano, T., pp. 45-83, 1976.

3. Hausenbuiller, R. L., Soil Science - Principles and Practices, William C. Brown Company Publishers, Dubuque, Iowa, 1972.

4. Stevens, R. M., Green Land - Clean Streams, Center for the Study of Federalism Report on the Beneficial Use of Water Through Land Treatment, Temple University, Philadelphia, PA, 1972.

5. Environmental Protection Agency, Technology Transfer, Land Treatment of Municipal Wastewater Effluents, Design Factors I, II, January 1976.

6. Sopper, W. E., "Use of the Soil-Vegetation Biosystem for Wastewater Recycling," Land Treatment and Disposal of Municipal and Industrial Wastewaters, Sanks, R. L. and Asano, T., pp. 17-44, 1976.

7. Kincannon, C. B., "OiTy Waste Disposal by Soil Cultivation," Proceedings of the Open Forum on Management of Petroleum Refinery Wastewaters, Environmental Protection Agency, pp. 257-272, 1976.

8. Huddleston, R. L. and L. C. Cresswell, "The Disposal of Oily Wastes by Land Farming," Proceedings of the Open Forum on Management of Petroleum Refinery Wastewater, Environmenta7 Protection Agency, pp. 273-292, 1976.

9. Neal, D. M., R. L. Glover and P. G. Moe, "Land Disposal of Oily Wastewater by Means of Spray Irrigation," Land as a Waste Management Alternative, Proceedings of the 1976 Cornell Agricultural Waste Management Conference, Lochr, R. C., editor, pp. 757-768, 1977.

10. Harris, J. 0, "Petroleum Wastes in the Soil," Land Application of Waste Materials, Soil Conservation Society of America, pp. 249-253, 1976.

11. Kimba11, V. S., "Disposal by Land Spreading," Waste 0il Recovery and Disposal, Noyes Data Corporation, Park Ridge, NJ, Chapter 10, pp. 212-270, 1975.

12. Lee, G. F., "Potential Problems of Land Application of Domestic Wastewaters," Land Treatment and Disposal of Municipal and Industrial Wastewater, Sanks, R. L. and Asano, T., editors, pp. 179-192, 1976. 
13. Sidle, R. C., J. E. Hook and L. T. Kardos, "Accumulation of Heavy Metals in Soils from Extended Wastewater Irrigation," Journal Water Pollution Control Federation, pp. 317-318, February 1977.

14. Bower, H., "Improvement of Wastewater Quality by Movement Through Soils and Aquifers," Biological Control of Water Pollution, Tourbier, J., Pierson, R. W., Jr., editors, University of PennsyTvania Press, pp. 259-268, 1976.

15. Pound, C. E. and R. W. Crites, "Land Application Practices and Design Criteria," Land Application of Wastewater, Environmental Protection Agency, pp. 13-26, May 1, 1975.

16. Environmental Protection Agency. "Land Treatment of Municipal Wastewater Effluents, Case Histories, Technology Transfer, January 1976.

17. Norum, E. M., "Design and Operation of Spray Irrigation Systems," Land Treatment and Disposal of Municipal and Industrial Wastewater, Sanks, R. L., Asano, T., pp. 25-288, 1976.

18. Wallace, A. T., "Land Disposal of Liquid Industrial Wastes," Land Treatment and Disposal of Municipal and Industrial Wastewaters, Sanks, R. L., Asano, T., pp. 147-162, 1976.

19. Bouwer, H., "Infiltration-Percolation Systems," Land Application of Wastewater, Environmental Protection Agency, pp. 85-92, May 1, 1975.

20. Crites, R. W., "Land Treatment of Wastewater by Infiltration-Percolation," Land Treatment and Disposal of Municipal and Industrial Wastewater, Sanks, R. L., Asano, T., pp. 193-212, 1976.

21. Reed, S., et a1., Wastewater Management by Disposal on the Land, Cold Regions Research and Engineering Laboratory, Corps of Engineers, May 1972.

22. Hunt, P. G. and C. R. Lee, "Land Treatment of Wastewater by Overland Flow for Improved Water Quality, "Biological Control of Water Pollution, Tourbier, J., Pierson, R. W., Jr., editors, University of Pennsyivania Press, pp. 151-160, 1976.

23. Wallace, A. T., "Land Disposal of Liquid Industrial Wastes," Land Treatment and Disposal of Municipal and Industrial Wastewater, Sanks, R. L. and Asano, T., editors, pp. 147-162, 1976.

24. Parizek, R. R., "Site Selection Criteria for Wastewater Disposal-Soils and Hydrogeologic Considerations," Conference on Recycling Treated Municipal Wastewater Through Forest and Cropland, Environmental Protection Technology Series, EPA-660/2-74-003, March 1974. 
25. Ferguson, A. H., "Acceptability of Wastewater Effluents by Soils," Land Treatment and Disposal of Municipal and industrial Wastewater, Sanks, R. L., Asano, T., pp. 85-100, 1976.

26. Culp, G. L. and D. J. Hinricks, "Management Alternatives for Land Treatment Systems," Public Works, 108(6), pp. 78-79, June 1977.

27. Sanks, R. L., Asano, T. and A. H. Ferguson, "Engineering Investigations for Land Treatment and Disposal," Land Treatment and Disposal of Municipal and Industrial Wastewater, Sanks, R. L., Asano, T., pp. T-16, 1976.

28. Willems, D. G., "Land Treatment of Wastewaters--Institutional and Regulatory Agency Approach," Land Treatment and Disposal of Municipal and Industrial Wastewater, Sanks, R. L., Asano, T., pp. 1-16, 1976.

29. Koenig, A. and D. P. Loucks, "Management Model for Wastewater Disposal on Land," ASCE - Journal of the Environmental Engineering Division, 103(EE2), pp. 181-196, ApriT 1977.

30. Hoadley, A. W. and S. M. Goyal, "Public Health Implications of the Application of Wastewaters to Land," Land Treatment and Disposal of Municipal and Industrial Wastewaters, Sanks, R. L., Asano, T, pp. 101-132, 1976. 


\section{DISTRIBUTION}

No. of

Copies

\section{OFFSITE}

A. A. Churm

DOE Patent Division

9800 S. Cass Avenue

Argonne, IL 60439

27 DOE Technical Information Center

5 W. E. Mott, Director

Division of Environmental Control Technology

Department of Energy

Washington, DC 20545

C. Y. Cha

Occidental oil Shale, Inc.

6000 Stockdale Highway

Bakersfield, CA 93309

P. Fox

Lawrence Berkely Laboratory

University of California

Berkeley, CA 94720

R. N. Heistand

Development Engineering, Inc.

300 Enterprise Building

Grand Junction, CO 81501

H. B. Jensen

Talley Energy Systems, Inc.

7333 East Monteray Way

Suite 11

Scottsdale, AR 85251

J. C. Knepper

Rio Blanco Oil Shale Company

Dayton Commons

9725 East Hampden Avenue

Denver, CO 80231
No. of

Copies

M. A. Lekas

Geokinetics, Inc.

280 Buchanan Field Road

Concord, CA 94520

K. D. Linstedt

University of Colorado

Bculder, CO 80309

P. E. Poulson

Laramie Energy Research Center

Department of Energy

P.0. Bcx 3395, University Station

Laramie, WY 82071

T. J. Powers

U.S. Environmenta I Protection Agency

555 Ridge Avenue

Cincinnati, OH 45268

A. J. Rothman

Lawrence Berkeley Laboratory

P.0. Box 808, M.S. L-207

Livermore, CA 94550

A. Sass

Occidental 0 il Shale, Inc.

6000 Stockdale Highway

Bakersfield, CA 93309

J. J. Schmidt-Collerus

Denver Research Institute

University of Denver

Denver, CO 80201

T. F. Yen

University of Southern California

University Park

Los Angeles, CA 90007 
No. of

Copies

DOE Richland Operations

H. E. Ransom

70 Pacific Northwest Laboratory

W. J. Bair

A. C. Campbell

D. B. Cearlock

G. W. Dawson

J. S. Fruchter

T. R. Garland

S. Marks

B. W. Mercer (50)

W. Wakamiya

Publishing Coordination (2)

Technical Information (5)

Water and Land Resources

Ro

Library (5) 